\title{
Evolution of the Experimental Models of Cholangiocarcinoma
}

\author{
Annamaria Massa ${ }^{1}$, Chiara Varamo ${ }^{2,3}$, Francesca Vita ${ }^{2}$, Simona Tavolari ${ }^{4}$, \\ Caterina Peraldo-Neia ${ }^{5}$, Giovanni Brandi ${ }^{6}$, Alessandro Rizzo ${ }^{6}{ }^{\mathbb{D}}$, Giuliana Cavalloni ${ }^{1}$ and \\ Massimo Aglietta 1,2,* \\ 1 Division of Medical Oncology, Candiolo Cancer Institute, FPO-IRCCS, Candiolo, 10060 Torino, Italy; \\ annamaria.massa@ircc.it (A.M.); giuliana.cavalloni@ircc.it (G.C.) \\ 2 Department of Oncology, University of Turin, 10126 Torino, Italy; chiara.varamo@ircc.it (C.V.); \\ francesca.vita@ircc.it (F.V.) \\ 3 Department of Oncology, Laboratory of Tumor Inflammation and Angiogenesis, B3000 KU Leuven, Belgium \\ 4 Center for Applied Biomedical Research, S. Orsola-Malpighi University Hospital, 40138 Bologna, Italy; \\ simona.tavolari@unibo.it \\ 5 Laboratory of Cancer Genomics, Fondazione Edo ed Elvo Tempia, 13900 Biella, Italy; \\ caterina.peraldoneia@ircc.it \\ 6 Department of Experimental, Diagnostic and Specialty Medicine, S. Orsola-Malpighi University Hospital, \\ 40138 Bologna, Italy; giovanni.brandi@unibo.it (G.B.); rizzo.alessandro179@gmail.com (A.R.) \\ * Correspondence: massimo.aglietta@ircc.it
}

Received: 30 July 2020; Accepted: 14 August 2020; Published: 17 August 2020

check for updates

\begin{abstract}
Cholangiocarcinoma (CCA) is a rare, aggressive disease with poor overall survival. In advanced cases, surgery is often not possible or fails; in addition, there is a lack of effective and specific therapies. Multidisciplinary approaches and advanced technologies have improved the knowledge of CCA molecular pathogenesis, highlighting its extreme heterogeneity and high frequency of genetic and molecular aberrations. Effective preclinical models, therefore, should be based on a comparable level of complexity. In the past years, there has been a consistent increase in the number of available CCA models. The exploitation of even more complex CCA models is rising. Examples are the use of CRISPR/Cas9 or stabilized organoids for in vitro studies, as well as patient-derived xenografts or transgenic mouse models for in vivo applications. Here, we examine the available preclinical CCA models exploited to investigate: (i) carcinogenesis processes from initiation to progression; and (ii) tools for personalized therapy and innovative therapeutic approaches, including chemotherapy and immune/targeted therapies. For each model, we describe the potential applications, highlighting both its advantages and limits.
\end{abstract}

Keywords: cholangiocarcinoma; experimental models; animal models; cell lines; tumor microenvironment; spheroids; cancer stem cells; organoids

\section{Introduction}

Cholangiocarcinoma (CCA) is a heterogeneous group of tumors originating from the epithelium of biliary tract. It represents the second most common primary liver malignancy after hepatocellular carcinoma (HCC) [1]. Based on its anatomical origin, CCA is classified as intrahepatic (iCCA), which accounts for $10 \%$ of CCA [2], and extrahepatic (eCCA), which is more frequent, further subdivided in perihilar (pCCA) and distal (dCCA) [3]. According to the recent WHO classification, 5th edition, iCCA is reclassified in: (i) large duct type, which is similar to extrahepatic cholangiocarcinoma; and (ii) small duct type, which resembles hepatocellular carcinoma. The two subtypes display different molecular and genetic aberrations, histological features, and clinical outcome [4]. 
CCA has different rates of incidence worldwide, with more cases in Eastern countries, but with an increasing rate in Western countries in the last three decades [5]. Its incidence and risk factors (e.g., primary sclerosing cholangitis, parasitic infections, chemical carcinogens, etc.) are geographically related [3,5-7]. CCA is an aggressive tumor, with a 5-year survival rate of 5-15\% for inoperable cases [8]. The only potentially curative treatment is surgery; however, most patients are diagnosed at an advanced stage when resection is no longer possible. For unresectable or metastatic patients, the backbone treatment is gemcitabine (GEM) \pm platinum derivatives [9-12]. Unfortunately, the improvement in terms of survival is modest, and the efficacy of this treatment is impaired by chemoresistance [13]. Other therapeutic strategies have been tested, but due to the genetic variability and the clonal evolution of CCA, clinical studies with targeted therapies (e.g., monoclonal antibodies and tyrosine kinase inhibitors against EGFR, VEGF, FGFR2) have shown minimal success in terms of overall survival (OS) [14]. On the basis of positive results obtained in the FIGHT-202 study [15], the U.S. FDA has recently approved the anti-FGFR2 antibody pemigatinib (Pemazyre) in CCA patients harboring FGFR2 gene fusions (9-14\% of patients) previously treated with chemotherapy. This trial is ongoing.

Recent advances in high-throughput techniques, such as next-generation sequencing and other "omics" approaches, have provided an unprecedented opportunity to broaden our understanding of the molecular mechanisms driving CCA carcinogenesis, leading to an extremely large body of data that must be properly interpreted and translated into clinical practice. To address this challenge, generating CCA preclinical models has become crucial for: (i) elucidating the causes and molecular mechanisms involved in carcinogenesis, tumor progression, and metastatization; (ii) discovering both prognostic biomarkers and druggable targets; and (iii) testing the therapeutic effects of drugs and developing more efficient therapies.

The aim of this review is to describe all the preclinical models used for CCA research, focusing on their strengths and weaknesses.

\section{Evolution of in vitro CCA Models}

\subsection{D Models: Cell Lines and Primary Cell Cultures}

For several years, human or animal primary cultures and established cell lines have represented important in vitro models, widely used in cancer research to study the biology of cancer and to test the efficacy of anticancer drugs. Cell lines retain some genetic alterations and transcriptomic profiles detected in primary human tumors, allowing high-throughput screening studies to identify potential druggable targets, prognostic and predictive biomarkers of drug responses, and investigate mechanisms of tumorigenesis and drug resistance, exploiting the recently developed advanced genetic tools. However, some cell lines, generated from metastases or from patient-derived xenografts, display a genetic and molecular spectrum that does not completely recapitulate primary tumors [16-18].

The first established and characterized CCA cell line, named HChol-Y1, was obtained from iCCA patients 30 years ago by Yamaguchi et al. [19]. Subsequently, several other iCCA and eCCA cell lines, derived from primary tumors, ascites, metastases, and xenografts have been described in the literature (Table 1).

Most CCA cell lines have been characterized biologically, but only a few have been profiled molecularly (e.g., mutational status, SNPs, rearrangements, alternative splicing, methylation, mRNA or non-coding RNA expression). Genomic studies on CCA patients have highlighted some frequent genomic alterations, including mutations of TP53 and SMAD4, ARID1A, ARID2, BAP1, KRAS, PIK3CA, NRAS, and IDH1 genes [20-24], mutations and/or amplification of the EGFR family member genes [21], and the rearrangement of the FGFR2 receptor [25]. The work of Akita et al. [26] found that IDH1 mutation is typical in iCCA derived from small bile duct as well as the loss of BAP1; in contrast, loss of SMAD4 expression, KRAS mutations, and MDM2 amplification are mainly found in large bile duct iCCA. A very recent study has focused on the in-depth characterization of 22 CCA cell lines, including gallbladder carcinoma, by exome sequencing, copy number, and RNA-seq analyses [27]. This large 
panel of cell lines, which differ in their site of origin, molecular alterations, and mutational status, represents a valid tool for drug screening tests, in particular for targeted therapy (Table 1).

Table 1. Cholangiocarcinoma (CCA) cell lines described in the literature and some of their genetic/molecular characteristics and drug resistance.

\begin{tabular}{|c|c|c|c|c|}
\hline $\begin{array}{c}\text { Cell } \\
\text { Line/References }\end{array}$ & $\begin{array}{c}\text { Anatomic } \\
\text { Site/Classification }\end{array}$ & Source & $\begin{array}{c}\text { Genetic-Molecular } \\
\text { Alterations/References }\end{array}$ & $\begin{array}{c}\text { Drug } \\
\text { Resistance/References }\end{array}$ \\
\hline HChol-Y1/[19] & iCCA & PT & NA & \\
\hline $\mathrm{Oz} /[28]$ & iCCA & Ascites/Mts & mKRAS/[27] & \\
\hline $\mathrm{HuH} 28^{\mathrm{a}-\mathrm{c}} /[29]$ & iCCA & PT & $\begin{array}{c}\text { mPIK3CA, mARID1A; mARID2; } \\
\text { mMLH3; mTP53/[30]; Depmap portal }\end{array}$ & $\begin{array}{c}\text { Gem }^{\mathrm{a}} /[31] \\
\text { Anti-EGFR Ab } \\
\text { Mek inhibitors }{ }^{\mathrm{c}} /[32]\end{array}$ \\
\hline CHGS/[33] & iCCA & PT & NA & \\
\hline $\mathrm{HuCC}-\mathrm{T} 1 \mathrm{c}, \mathrm{d} /[34]$ & iCCA & Ascites/Mts & $\begin{array}{c}\text { mKRAS; iMSH6; mTP53; high level } \\
\text { protein BAP1/ } \\
\text { [27,35]; CCLE; Cosmic-CLP }\end{array}$ & $\begin{array}{l}\text { FGFR inhibitors } \mathrm{c} /[36] \\
\text { EGFR inhibitors } \mathrm{d} /[\mathrm{[37]}\end{array}$ \\
\hline RGHuCC-T1 $^{\mathbf{b}}$ & iCCA & Ascites/Mts & & $\mathrm{Gem}^{\mathbf{b}} /[38]$ \\
\hline PCI:SG231/[39] & iCCA & PT & NA & \\
\hline HuCCA-1 a/[40] & iCCA & PT & NA & $5-\mathrm{FU} \mathrm{a} /[41]$ \\
\hline KMC-1/[42] & iCCA & PDX & mKRAS/[43] & \\
\hline CC-SW-1/[44] & iCCA & PT & mBRAF/Depmap portal & \\
\hline CC-LP-1/[44] & iCCA & PT & $\begin{array}{l}\text { high level protein BAP1; mTP53; } \\
\text { mBAP1/[35] }\end{array}$ & \\
\hline CC-LP-1GR ${ }^{\mathbf{b}}$ & iCCA & PT & & $\mathrm{Gem}^{\mathbf{b}} /[45]$ \\
\hline $\mathrm{KMCH}-2 /[46]$ & iCCA-HCC & PT & NA & \\
\hline ETK1/[47] & iCCA & Ascites, Mts & mPIK3C3; mTP53/Depmap portal & \\
\hline $\mathrm{RBE}^{\mathrm{c}} /[47]$ & iCCA & PT & $\begin{array}{c}\text { mIDH1; mBIRC6; mMSH6; mMSH3; } \\
\text { mKRAS/ } \\
\text { [48]; Depmap portal }\end{array}$ & FGFR inhibitors ${ }^{\mathrm{c}} /[36]$ \\
\hline SSP-25 c/[47] & iCCA & PT & mTP53/Depmap portal & FGFR inhibitors ${ }^{c} /[36]$ \\
\hline RPMI 7451/[49] & iCCA & PT & NA & \\
\hline SNU-1079 c/[50] & iCCA & PT & $\begin{array}{l}\text { mIDH1; dARID1A; mPIK3AP1/[27]; } \\
\text { Depmap portal }\end{array}$ & FGFR inhibitors ${ }^{\mathrm{c}} /[36]$ \\
\hline KKU-M055/[51] & iCCA & PT & $\begin{array}{c}\text { mMA2K1; high level mRNA } \\
\text { FGFR1/[27] }\end{array}$ & \\
\hline KKU-M156 a/[51] & iCCA & PT & NA & Cis, Carbo a/[51] \\
\hline KKU-M214/[51] & iCCA & PT & NA & \\
\hline KKU-M214R ${ }^{\mathbf{b}}$ & iCCA & PT & & Gem, 5-FU, Doxo, PTX b/[52] \\
\hline KKU-OCA17/[51] & iCCA & PT & NA & \\
\hline HKGZ-CC/[52] & iCCA & PT & mKRAS; mTP53/Depmap portal & \\
\hline NCC-CC1/[53] & iCCA & PDX & mKRAS; mTP53/[53] & \\
\hline NCC-CC3-1/[53] & iCCA & PDX & mKRAS/[53] & \\
\hline NCC-CC3-2/[53] & iCCA & PDX & mKRAS/[53] & \\
\hline NCC-CC4-1/[53] & iCCA & PDX & NA & \\
\hline KKU-M213/[54] & iCCA & PT & $\begin{array}{l}\text { mKRAS; mTP53; mSMAD4/[27]; } \\
\text { Depmap portal }\end{array}$ & \\
\hline HCCC-9810/[55] & iCCA & PT & NA & \\
\hline MT-CHC01 c/[56] & iCCA & PDX & mKRAS, aErbB2, dTP53/[56] & $\begin{array}{l}\text { Anti-EGFR Ab }{ }^{\mathrm{c}} \\
/[32]\end{array}$ \\
\hline $\begin{array}{l}\text { MT-CHC01R1.5 } \\
\text { b/[57] }\end{array}$ & iCCA & PDX & & Gem, 5-FU, Carbo b/[57] \\
\hline KKU-023/[58] & iCCA & PT & mTP53/[58] & \\
\hline ZJU-1125/[59] & iCCA & PT & mTP53/[59] & \\
\hline KKK-D049/[60] & iCCA & PDX & NA & \\
\hline KKK-D068/[60] & iCCA & PDX & NA & \\
\hline TKK/NA & iCCA & PT & high level mRNA ErbB2; aErbB2 [27] & \\
\hline YSCCC NA & iCCA & PT & mTP53/Depmap portal & \\
\hline
\end{tabular}


Table 1. Cont

\begin{tabular}{|c|c|c|c|c|}
\hline $\begin{array}{c}\text { Cell } \\
\text { Line/References }\end{array}$ & $\begin{array}{c}\text { Anatomic } \\
\text { Site/Classification }\end{array}$ & Source & $\begin{array}{c}\text { Genetic-Molecular } \\
\text { Alterations/References }\end{array}$ & $\begin{array}{c}\text { Drug } \\
\text { Resistance/References }\end{array}$ \\
\hline KKK-D068/[60] & iCCA & PDX & NA & \\
\hline YSCCCG100 $\mathbf{b}$ & iCCA & PT & & $\mathrm{Gem}^{\mathbf{b}} /[61]$ \\
\hline KKU-M139/NA & iCCA & PT & NA & \\
\hline KKU-M139R b & iCCA & PT & & Gem, 5-FU, Doxo, PTX b/[62] \\
\hline $\mathrm{HBDC} /[63]$ & eCCA/pCCA & $\begin{array}{c}\text { Ascites, } \\
\text { Klatskin-Mts }\end{array}$ & NA & \\
\hline SNU-1196/[50] & eCCA/pCCA & PT, Klatskin & $\begin{array}{l}\text { aKRAS, mTP53; mSMAD6/[27,50]; } \\
\text { Depmap portal }\end{array}$ & \\
\hline KKU-100/[64] & eCCA/pCCA & PT, Klatskin & $\begin{array}{l}\text { mKRAS; mTP53; mFGFR3/[58]; } \\
\text { Depmap portal }\end{array}$ & \\
\hline KKU-452/[58] & eCCA/pCCA & PT & mTP53/[58] & \\
\hline ZJU-0826/[59] & eCCA/pCCA & PT & NA & \\
\hline SNU-478/[50] & eCCA/dCCA & $\begin{array}{l}\text { PT/Ampulla of } \\
\text { Vater }\end{array}$ & mMLH1; mTP35/[50] & \\
\hline SNU-869/[50] & eCCA/dCCA & $\begin{array}{l}\text { PT/Ampulla of } \\
\text { Vater }\end{array}$ & mKRAS; mPI3K, mTP53/[27,30,50] & \\
\hline TGBC-51/[65] & eCCA/dCCA & $\begin{array}{l}\text { PT/Ampulla of } \\
\text { Vater }\end{array}$ & NA & \\
\hline TGBC18TKB/NA & eCCA/dCCA & $\begin{array}{l}\text { PT/Ampulla of } \\
\text { Vater }\end{array}$ & $\begin{array}{l}\text { mErbB2; mBRAF; high level mRNA } \\
\text { ErbB2/[27] }\end{array}$ & \\
\hline EGI-1 d/c/[66] & eCCA/dCCA & PT & $\begin{array}{l}\text { mKRAS; mTP53/[27]; CCLE; } \\
\text { Cosmic-CLP }\end{array}$ & $\begin{array}{l}\text { EGFR inhibitors d/[37] } \\
\text { Anti-EGFR } \mathrm{Ab}^{\mathrm{c}} /[\mathrm{[32]}\end{array}$ \\
\hline Sk-ChA-1 d/[67] & eCCA & Ascites/Mts & mBRAF; tmRASA1/[27] & EGFR inhibitors d/[37] \\
\hline $\mathrm{MEC} /[68]$ & eCCA & $\begin{array}{c}\text { Pleural } \\
\text { Effusion/Mts }\end{array}$ & NA & \\
\hline KMBC/[69] & eCCA & PT & $\mathrm{NA}$ & \\
\hline TFK-1 c/[70] & eCCA/dCCA & PT & $\begin{array}{l}\text { mTP53; mMSH6; mFRFR3/[71]; } \\
\text { Depmap portal }\end{array}$ & $\begin{array}{l}\text { Anti-EGFR } \mathrm{Ab}^{\mathrm{c}} ; \text { Mek } \\
\text { inhibitors }{ }^{\mathrm{c}} /[32]\end{array}$ \\
\hline TFK-1GR ${ }^{\mathbf{b}}$ & eCCA/dCCA & PT & & $\mathrm{Gem}^{\mathbf{b}} /[72]$ \\
\hline OCUCh-LM1/[73] & eCCA & Liver Mts & NA & \\
\hline QBC939/[74] & eCCA & PT & NA & \\
\hline $\mathrm{RGQBC} 9^{\mathbf{b}}$ & eCCA & PT & & $\mathrm{Gem}^{\mathbf{b}} /[38]$ \\
\hline ICBD-1/[75] & eCCA & PT & NA & \\
\hline TK/[76] & eCCA & Ascites/Mts & NA & \\
\hline $\mathrm{SCK} /[77]$ & eCCA & PT & NA & \\
\hline SCK-R ${ }^{b}$ & eCCA & PT & & $\begin{array}{c}\text { Gem; } 5-F U, C \text { is } \\
\text { b/[78] }\end{array}$ \\
\hline JCK/[77] & eCCA & PT & NA & \\
\hline Cho-CK/[77] & eCCA & PT & NA & \\
\hline Choi-CK/[77] & eCCA & PT & NA & \\
\hline SNU-245/[50] & eCCA/dCCA & PT & mBIRC6; mTP53/Depmap portal & \\
\hline TGBC-47/[65] & eCCA & PT & NA & \\
\hline TBCN-6/[65] & eCCA & PT & NA & \\
\hline RMCCA-1/[79] & eCCA/pCCA & PT & NA & \\
\hline NCC-BD1/[53] & eCCA & PDX & mKRAS; mTP53/[53] & \\
\hline NCC-BD2/[53] & eCCA & PDX & mTP53/[53] & \\
\hline $\mathrm{KMCH}-1$ c/[80] & $\mathrm{CCA} / \mathrm{HCC}$ & PT & $\begin{array}{l}\text { mPTEN; dARID1A; mMSH4; } \\
\text { mBRAF/OMICS; depmap portal }\end{array}$ & $\begin{array}{c}\text { Anti-EGFR Ab; Mek } \\
\text { inhibitors }{ }^{c} \\
/[32] \\
\end{array}$ \\
\hline \multicolumn{5}{|c|}{ 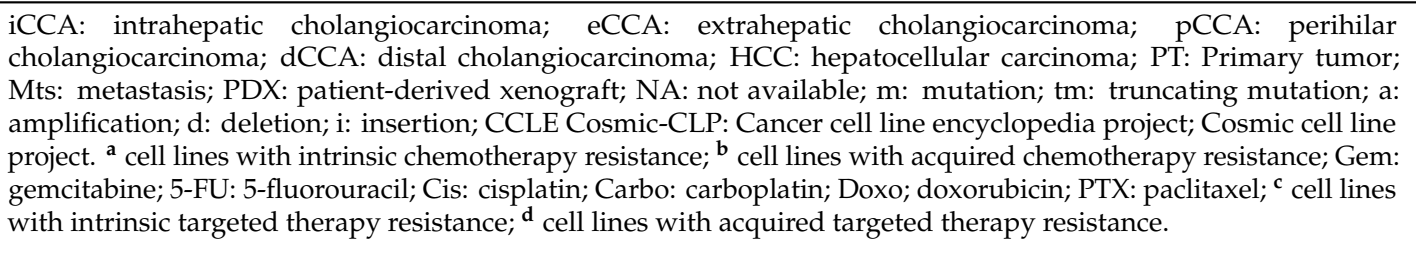 } \\
\hline
\end{tabular}


Molecular profiling analyses of most established models have been carried out without contemplating the eCCA subdivision and before the new iCCA guidelines (e.g., 5th WHO classification) [4], thus the eCCA (pCCA/dCCA) and iCCA subcategories (large/small duct types) are often missing.

In this context, cancer cell lines may be helpful to either investigate the response to drugs (e.g., chemotherapy and targeted therapy) or to probe the mechanisms underlying a potential resistance to therapy. In fact, some cell lines can be primarily resistant, retaining this feature from the primary tumor, or can acquire resistance with drug treatment. Several mechanisms involved in chemotherapy resistance have already been elucidated, including the high expression of drug efflux pumps, the increase in detoxification of chemotherapeutic drugs, the alteration of drug targets, and the inhibition of drug-induced apoptosis [81,82].

Concerning resistance to targeted therapy (in particular to anti-EGFR, and anti-FGFR therapies) distinct mechanisms have been proposed, including mutations in the target, reactivation of the targeted pathway, or activation of alternative pathways $[83,84]$. Table 1 reports some chemo/targeted therapy resistant CCA models.

Important advancements in the discovery of carcinogenesis and molecular targets have been achieved in vitro with the powerful CRISPR/Cas9 gene editing system, a genetic tool able to identify and execute cleavage at specific DNA sites [85]. One example of CRISPR/Cas9 application in CCA is the recent work by Yoshino et al. in which the role of ARID1A (AT-rich interactive domain-containing protein 1A) was investigated by means of gene editing. Clinically, it was demonstrated that ARID1A-negative iCCA patients had a poorer outcome compared to ARID1A-positive ones, suggesting that ARID1A may have prognostic value in iCCA [86]. To explore the role of ARID1A, the authors established ARID1A-knockout (KO) human iCCA cell lines by using the CRISPR/Cas9 system. Compared to wild type (WT), ARID1A-KO cells developed a more malignant and aggressive phenotype, as demonstrated by significantly enhanced migration, invasion, and sphere-formation ability and by concomitant high expression levels and activity of the stemness gene ALDH1A1 [86]. The CRISPR/Cas9 approach is an efficient and simple method to: (i) clarify the mechanisms of tumorigenesis, (ii) identify novel molecular targets for drug development, and (iii) potentially create engineered cells for cell-based therapies [87]. However, this technology still requires improvements in terms of efficacy and safety before its clinical translation [88].

Established cancer cell lines are the most accessible and easy models used for genome editing in vitro and for investigating tumor evolution. However, due to increasing passage numbers, which cause variations in both genotype and phenotype, they poorly reflect the behavior and heterogeneity of tumors in vivo [89]. In contrast, primary monocultures created by tumor tissue dissociation [90] retain the morphological and functional characteristics of their tissue of origin, so they are often used as a source of material for "omic" and functional studies. In addition, the culture conditions of primary cells are designed to limit cell differentiation and partially preserve the cancer stem cell (CSC) subpopulation, reflecting tumor heterogeneity.

Despite these advantages, primary cells are not yet fully representative of in vivo tumors, since they lack the tumor microenvironment (TME). The TME is a complex structure surrounding the tumor mass composed of a cellular part (stromal cells) and of a non-cellular part (the extracellular matrix, ECM, consisting of proteoglycans, hyaluronic acid, collagen, fibronectin, and laminin) [91]. Stromal cells, including cancer-associated fibroblasts (CAFs), mesenchymal stromal cells (MSCs), immuno-inflammatory cells, and vascular endothelial cells, create a dynamic interaction with the tumor that influences and favors its survival and progression [92]. Introducing models in which CCA cell lines or primary cells are co-cultured with stromal cells has contributed to the study of both tumor progression and drug response mechanisms by focusing on the crosstalk between the tumor and its TME. Several studies have shown the possibility of isolating neoplastic cholangiocytes (method described by Fabris et al.) [93] and stromal fibroblasts (Holt's method) [44] in order to study the interactions between CCA and mesenchymal cells, and to investigate pathways activated by their 
interaction [93-95] in 2D co-culture systems. Among all stromal cells present in the TME, CAFs are one of the most critical and abundant components. In order to investigate the molecules activated by tumor stroma-TME interaction, Ohira et al. demonstrated that, by co-culturing fibroblasts and two different iCCA cell lines, CCA-associated fibroblasts express SDF-1, promoting the invasion and migration of tumor cells via the SDF-1/CXCR4 molecular axis [96]. In vitro studies indicate that SDF-1 expression induces a number of pro-tumorigenic responses, such as $\mathrm{Bcl}-2$, and activates the PI3K/Akt pathway, promoting increased CCA cell invasion, prolonged survival, and epithelial-to-mesenchymal transition [97]. Another study using 2D co-culture systems showed that the contact of $\alpha$-Smooth Muscle-Actin-positive ( $\alpha$-SMA) myofibroblastic CAFs and iCCA cells increased tumor cell proliferation and switched cells into the active stages of the cell cycle [98].

In the crosstalk between CAFs and cancer cells, exosomes play an important role [91,99]. Exosomes are membrane-wrapped extracellular vesicles containing microRNAs, DNA fragments, proteins, and other soluble factors. They are an important example of communication between cancer cells and TME by inducing either anti- or pro-tumor signaling pathways $[78,93,100]$. A study of co-culture system between CAFs and iCCA cells demonstrated that miR-195, carried by CAF-derived exosomes, could inhibit tumor proliferation and invasion in vitro [101]. Another study conducted by Chen et al. demonstrated that CCA-derived exosomes support iCCA cells to escape the attack of the immune system by preventing cytokine-induced killer (CIK) cells from producing molecules with anticancer effect, such as tumor necrosis factor (TNF)- $\alpha$ and perforin [102]. Hence, the in vitro study of exosomes-TME interactions may be important for the development of new therapeutic approaches.

\subsubsection{Strengths and Weaknesses of 2D Models}

Although cell lines have, for decades, represented a useful tool for cancer research (long-term expansion capacity, short replication doubling time, low maintenance costs, and high reproducibility of experiments) they have many limitations, namely: (i) the success rate of establishing cell lines is low (about 10\%) [66] due to an inadequate amount of tumor cells in surgical or bioptic samples where the necrotic tissue is predominant; (ii) even in optimal culture conditions, not all cancer cells are able to proliferate due to the concomitant and contaminating presence of tumoral fibroblasts; (iii) artificial and stressful culture conditions and the presence of serum do not allow the maintenance of the stem compartment, and favor the accumulation of new genomic alterations; (iv) in vitro stabilization often promotes the selection of homogeneous cell clones, not representative of tumor genetic heterogeneity, potentially being a bias for the translation of preclinical data in a clinical context; (v) cell lines lack the cancer stem cells (CSC) subset, which is partially maintained in primary cell cultures; (vi) cell lines proliferating as monolayer cultures lack polarization; and (vii) the 2D nature of the cultures and the absence of tumor stromal cells do not recapitulate the architecture and cell interaction of the complex TME $[66,89]$. Unlike in vivo tumors, the bi-dimensional organization permits homogeneous distribution of nutrients, cell signaling molecules, oxygen, and drugs.

Regarding the more complex primary cell cultures and different co-culture systems, they present another limitation - the short period of time to reach senescence, sometimes after only a few in vitro passages, impedes long-term experiments and their reproducibility. Moreover, primary cultures are often laborious and less efficient. This is particularly true in highly desmoplastic tumors such as CCA, where the overgrowth of stromal cells may significantly reduce the establishment efficiency [50].

In the last few years, more innovative in vitro models have been developed to improve 2D primary and cell line cultures; 3D models such as spheroids and organoids, discussed below, could be more promising models [103].

\subsection{D CCA Modeling Approaches}

Most cell types when placed into 2D cultures lose their differentiated phenotype. Interestingly, most of these cells maintain their physiological form and function when cultured in a 3D system [104]. This observation has led to the notion that the dimension in which cells are cultured in vitro (2D or 3D) 
is a crucial determinant of cell fate. The three-dimensional structure is a crucial characteristic of tissue and organ development; this level of organization starts during embryogenesis and continues with cell-to-cell interactions [105]. Furthermore, cells are enveloped by an ECM that affects their growth, differentiation, and homeostasis [106]. The development of three-dimensional systems has improved the study of the biochemistry and biology of tumors. A 3D architecture recapitulates the overall in vivo structure and composition of the tumor mass (including the stem cell niche), where the spatial arrangements reflect tumor cell-TME and -ECM interactions, also mimicking the biodistribution of nutrients, oxygen, stimuli, and drugs. However, the available methods often lack a precise control of cell external structures. Recently, the rapid development of bioengineering techniques, such as bioprinting, microfluidics, and photochemistry, has provided us with advantageous tools to reconstruct in vitro a 3D controllable tumor cell milieu [107]. For example, various biofunctionalized hydrogels have become the ideal candidates to acquire new insights into 3D models setup [108]. In the CCA scenario, however, these approaches are still poorly investigated. Recently, a prototype of 3D primary CCA cell culture was bioprinted using a composite hydrogel system of gelatin-alginate-Matrigel ${ }^{\mathrm{TM}}$ into a pre-designed grid architecture [109].

Conventional 2D cell cultures rely on the adherence to a flat and stiff surface to provide mechanical support for the cells. However, most of these 2D methods do not provide control of cell shape, which determines biophysical cues affecting cell bioactivities in vivo [110]. Differently, 3D microenvironments follow the distribution of cell-ECM and cell-cell interactions that influence most cellular behaviors and determine the functions of whole organs [111]. Cells in 2D move along a planar surface by generating enough traction to overcome surface inhibition. On the contrary, movements of cells in $3 \mathrm{D}$ arrangements are restricted by inhibition from contact with the surface, other cells, and/or the ECM [112].

Spheroid-like structures and in vitro multicellular tissue constructs, known as organoids, are the most frequent and well characterized 3D models of CCA.

\subsubsection{Spheroids}

The work by Sutherland et al. [113] paved the way to 3D cultures; they were the first to discover that lung cells grown in a floating manner would generate spheroids. Large spheroids $(>500 \mu \mathrm{m}$ in diameter) organize their structure by developing an outer zone containing proliferating cells, an intermediate zone containing a few mitosis-starved and poorly oxygenated cells, and a central zone of necrosis, a main feature of tumor bulks.

Spheroids can be generated from either primary cultures or cell lines cultured as a single- or multi-cell suspensions. Single cell suspension is generally maintained in the absence of a matrix, in low-density, attachment- and serum-free conditions to allow formation of floating spheres. Tumor cells within the spheroid closely interact with each other and such cell-cell interactions affect proliferation, survival, and response to therapy. Cell-cell adhesion is reinforced by the formation of desmosomes and dermal junctions. The close interactions between cells, coupled with the deposition of several ECM proteins (collagens, fibronectin, laminin, elastin, and tenascin), increases spheroid density, forming a physical barrier that prevents and limits the transport of drugs into the spheroid mass [114]. The absence of serum and the addition of growth factors that stimulate stem cell proliferation (EGF and FGFs, insulin, and hydrocortisone) promote the enrichment of a CSC-like population. In fact, only progenitor cells are able to generate spheroids in a starved medium [115].

CSCs are defined as initiating progenitors of cancer with self-renewal capacity, representing the tumor reservoir. They express tumor-specific stem markers, are poorly represented, quiescent, and resistant to chemotherapy [116-119]. CSCs have sufficient gene alterations to initiate a tumor, and more alterations arise during their differentiation into "mature" cancer cells.

CSC-enriched spheroids provide a 3D cell models to characterize CSC and to study their role in CCA development and in chemo-targeted therapy resistance [120]. Spheroids have been established from both CCA cancer cell lines and primary cultures. The pattern of protein expression in two eCCA cell 
lines (Mz-ChA-1 and SK-ChA-1) undergoing spheroid formation has been recently investigated [121]. Compared to 2D cultures, eCCA spheroids showed an increased expression of several enzymes involved in glycolysis, hypoxia signaling, the protein ubiquitination pathway, the NADH repair pathway, and the degradation of superoxide radicals [72]. In another study, spheroids were established from the iCCA cell lines SG231, HUCCT1, CCLP1, and CCA4; their molecular characterization revealed an increased expression of key genes involved in pluripotency, self-renewal, drug-resistance, and survival, as well as stem-like surface markers [122]. Indeed, CCA spheroid (cholangiosphere) models, like those from other tumors, are characterized by the presence of putative CSC and by enhanced tumorigenicity in xenograft models [71] and chemoresistance [123,124]. However, CSC markers specific of CCA have not been extensively studied; immunophenotypic analysis showed the expression of canonical CSC markers (CD133, CD24, CD44, EpCAM, Sox2, Nanog, OCT3/4, CD49f, CD11, FoxA 1/2, PDX1, Sox17, CK7/19) [123,125]. CCA spheroids have been used to investigate CSC-mediated chemoresistance or specific invasive properties. For instance, Kawamoto et al. developed spheroids from an eCCA GEM-resistant cell line (TFK-1) and from iCCA cells established from a patient with a GEM-resistant tumor. They observed that Metronidazole reduced cancer stemness features in both types of GEM-resistant CCA spheroids [72]. Cholangiosphere models were also useful for studying tumor-stroma interactions by using either direct or indirect co-culture systems. In particular, Raggi et al. demonstrated that tumor associated macrophages (TAMs) exposed to conditioned medium of CSC-enriched spheroids derived from iCCA cells, increased their recruitment and polarization [122]. Differently, Campbell at al. described a model of multicellular spheroids established by co-culturing cells derived from iCCA formed in syngeneic rat liver with varying numbers of clonal $\alpha$-SMA-positive CAFs from the same tumor type within a type I collagen matrix. This model closely resembled the whole tissue samples of the parental tumor [126].

\subsubsection{Organoids}

A more recent and promising 3D culture system to bridge the gap between 2D cultures and in vivo animal models is represented by organoids, which are complex 3D structures with architectures and functions similar to in vivo organs. They originate from stem cell progenitors cultured in the presence of a scaffold (a synthetic basement membrane) that reproduces the in vivo ECM [127]. The ECM guarantees the interaction between tumor cells and the TME and represents a reservoir for stimuli (cytokines, chemokines, and growth factors) and enzymes of tissue remodeling [128,129]. Synthetic matrices, such as polymer hydrogels, polyethylene glycol (PEG) macromers, or collagen are the most common in vitro supports used to generate organoids. Organoid formation efficiency is affected by the mechanical properties of the matrix, with values mimicking physiological organ stiffness [130]. When reaching a certain size, organoids cease to proliferate and develop a necrotic core. The process of growth arrest is thought to be linked to two phenomena: a switch from a proliferative, stem-like state to a non-proliferative one, and the loss of cell viability in the inner core of the organoid. In fact, organoid vascularization remains the major challenge in this field [131].

The main feature of organoids is to recapitulate patient tumor bulk, when cultured in vitro or xenografted into immune-deficient mice.

Presently, organoids obtained with colorectal, pancreatic, and lung cancer tissues are reliable platforms for the identification of new therapeutic targets and drug screening [132-134]. Conversely, in CCA research, there are only 10 published articles about organoids (Table 2), demonstrating that these models are still poorly explored, and their reliability should be proved. 
Table 2. Organoid models in CCA studies.

\begin{tabular}{lll}
\hline Organoid Source & Study Function & References \\
\hline \multirow{3}{*}{ Human CCA patient } & Drug screening & \\
& Drug resistance & \\
& Cancer differentiation & \\
& Cell plasticity & \\
& CCA metabolism \\
& Personalized Radiosensitivity & \\
\hline Human cholangiocyte GE & Cancer gene function & {$[140]$} \\
\hline \multirow{2}{*}{ Human Hepatocytes GE } & Cancer initiation & {$[142]$} \\
\hline \multirow{2}{*}{ Human hepatocarcinoma patient } & Identification preventive therapies & Cancer differentiation \\
\hline
\end{tabular}

Briefly, human CCA organoid models were successfully generated from surgical specimens [135] and core needle biopsies [144]. The genetic aberrations of the parental tumor are maintained in the organoid cultures, with about $80 \%$ of concordance in terms of mutations between organoids and primary tumors $[135,144,145]$. Moreover, organoids are a potential tool for drug screening, as demonstrated by Broutier [135], who screened a library of 29 compounds in iCCA organoids derived from two patients. Thus, CCA organoids are promising in vitro models to screen drug sensitivity [138].

\subsubsection{Strengths and Weaknesses of 3D Models}

Spheroids are reproducible culture systems with affordable production costs. Primary cultures can generate spheroids in just a few days, while some cell lines, even when cultured in the best conditions, only form cellular aggregates. Spheroids recapitulate cell interactions, but both the original tumor stroma and vascular components are missing. The genetic and molecular characteristics are maintained, suggesting that they represent a reliable model for drug response assays.

Organoids are more costly, require a longer time for their generation (even weeks), and the stabilization success is lower than for spheroids. Although organoids do not maintain the stroma and vascular components of the in vivo tumor, they morphologically, genotypically, and histologically resemble the primary tumor, thus representing the in vitro model with the highest predictive patient-specific therapy response.

Overall, spheroids and organoids have proven to recapitulate the pathophysiological features of tumors better than 2D cell cultures, approaching the level of in vivo models. Undoubtedly, organoids preserve more adequately the cellular and molecular phenotypes of original patient tumors, providing a powerful tool to investigate the onset of disease, progression, as well as the development of more effective and personalized anticancer therapies. Figure 1 shows the evolution of in vitro cell cultures from 2D to 3D models. 


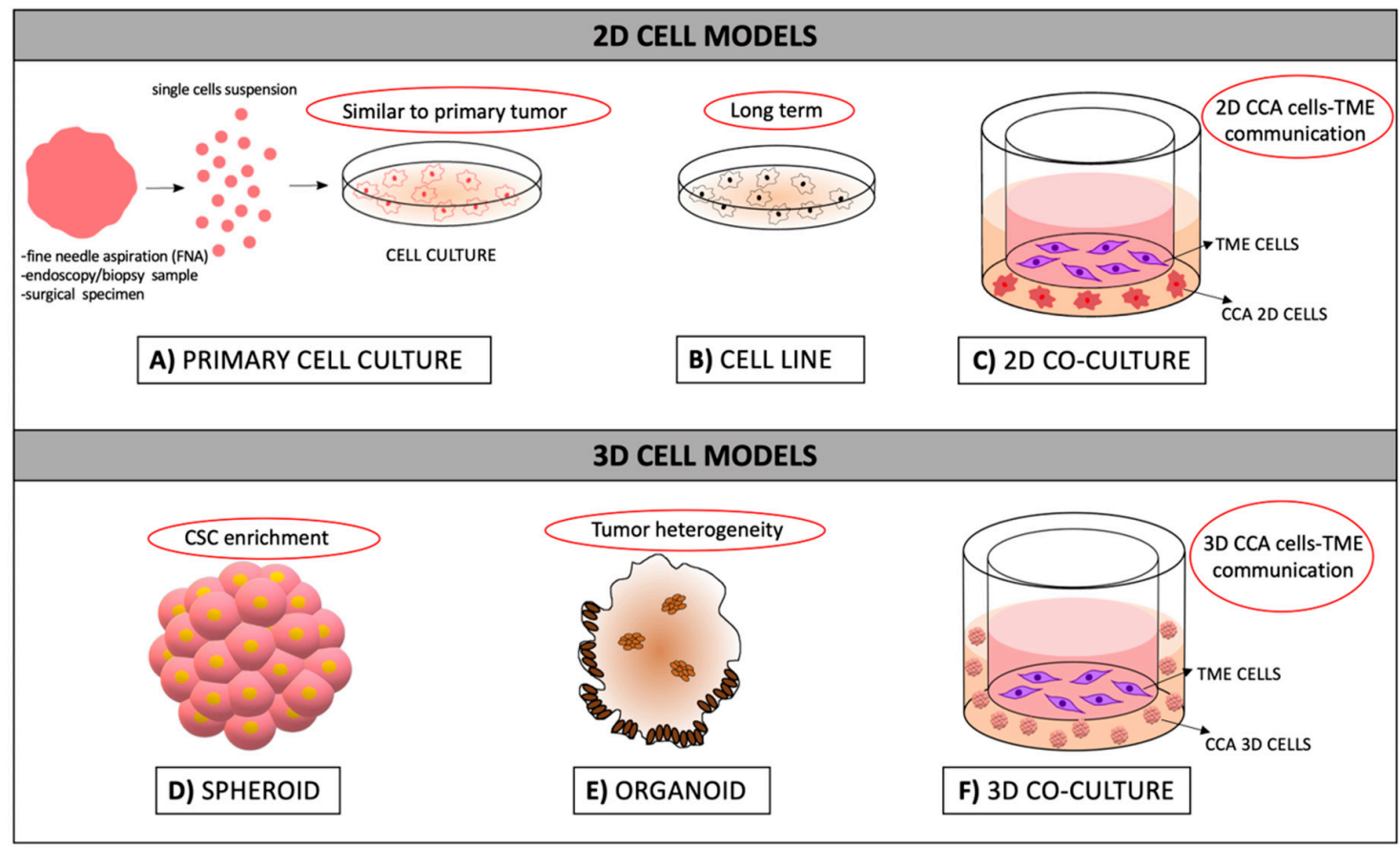

Figure 1. Schematic representation of in vitro experimental models used for investigating CCA. The upper section represents the most common 2D cell models, and the lower section shows the evolution of cell models in 3D cultures. In the red circles there are highlighted the peculiar features of each model. (A) Primary cell cultures were derived from surgical specimens mechanically, and enzymatically digested to obtain a single CCA cell suspension. (B) Established and characterized in vitro cell line. (C) Example of co-culture performed by Transwell assay to allow the crosstalk between tumor cells and TME cells; usually the TME cells are cultured in the upper compartment (e.g., stromal cells) and the CCA cells are plated in the lower compartment. (D) Spheroids are 3D floating cultures derived from CCA single cells, enriched in the putative CSC population. (E) Organoids are 3D structures with architectures and functions that are similar to in vivo organs; they are established from surgical specimens or biopsies, maintaining the genetic aberrations of the parental tumor. (F) Example of co-culture performed by Transwell assay to allow the crosstalk between 3D tumor cells, such as CCA spheroids and TME cells.

\section{Experimental Mouse Models in CCA}

Animal models are an intermediate step of experimentation between 2D/3D cell cultures and human clinical trials, and represent a powerful tool to study carcinogenesis, tumor progression, and to test efficacy and toxicity of therapeutic compounds.

Compared to the in vitro models, animal models closely resemble physiological conditions and faithful reproduction of the tumor and its TME, allowing a thorough study of: (i) the interaction between cancer cells and the TME, and (ii) the immune and vascular system response, which cannot be investigated in vitro.

Of all experimental animals, mice are the most commonly and traditionally used in CCA preclinical studies; they are small, easy to manipulate, reproduce quickly, and can be genetically modified. To date, many murine models have been developed for CCA, ranging from neoplastic transformation of biliary cells to CCA progression and metastatization. Below, the most used mouse models (Figure 2) are described and subdivided, according to their application: (i) the investigation of carcinogenesis and (ii) the identification of therapeutic approaches in CCA. 


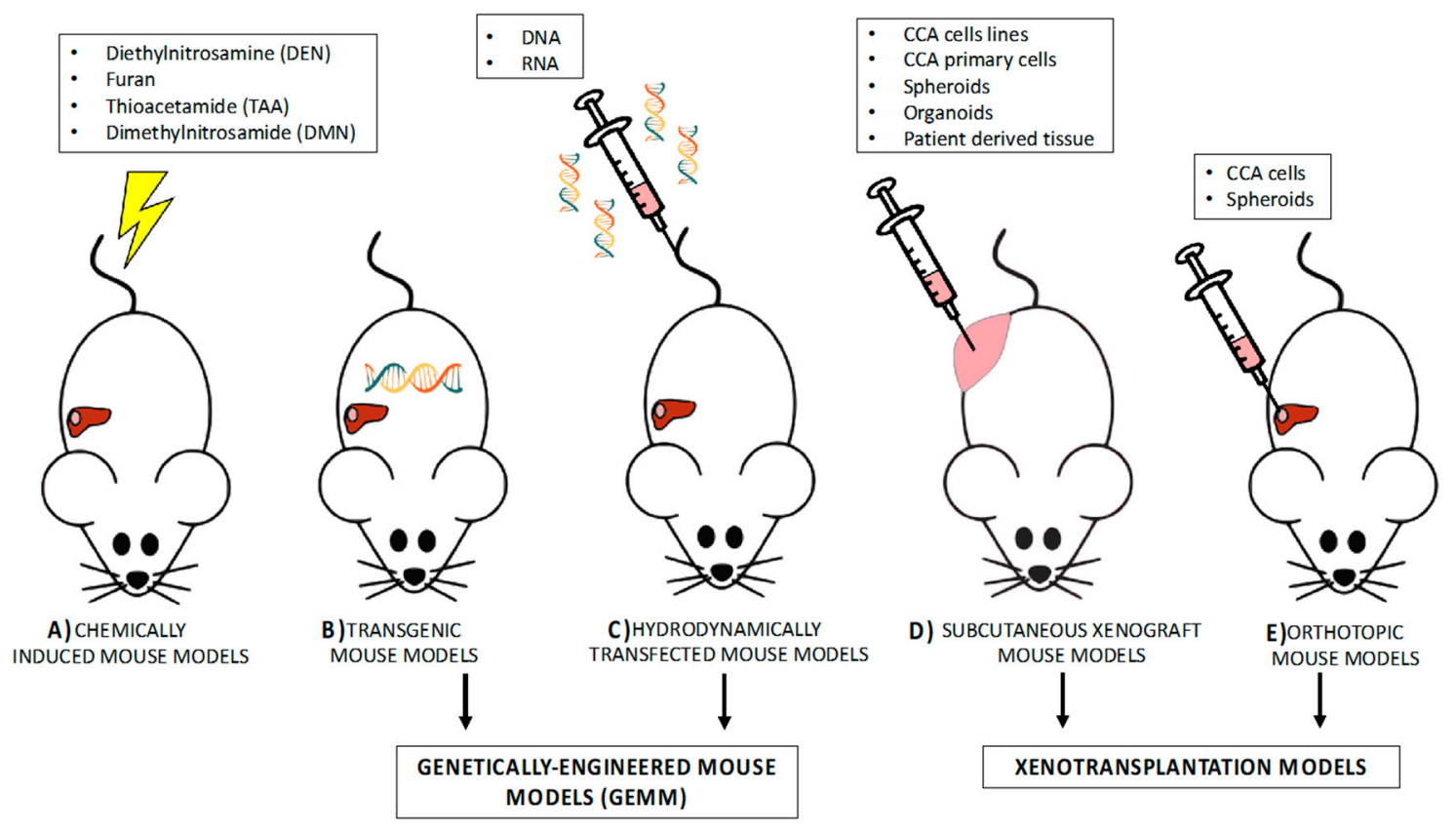

Figure 2. Mouse models of CCA. (A) Chemical carcinogens (DEN, furan, TAA, and DMN) administered to mice are able to induce CCA tumorigenesis. (B) Transgenic models are animals whose genome has been modified by introducing oncogenic sequences responsible for CAA induction. (C) Hydrodynamic transfection is used for delivering DNA or RNA into the tail vein and is considered to be an alternative for CCA germ-line knockout or CCA transgenic mice. $(B, C)$ are included in the genetically-engineered mouse models (GEMM). (D) Xenografts are models of a heterotopic graft, which involve the ectopic (subcutaneous) injection of CCA human cells, spheroids, organoids, or patient-derived tissue in immunodeficient or nude mice. (E) Orthotopic xenograft models accurately recapitulate the TME, since CCA cells or spheroids are directly injected into mouse portal or splenic veins, or into liver parenchyma. $(\mathbf{D}, \mathbf{E})$ are of xenotransplantation models.

\subsection{Investigating Carcinogenesis by Means of Rodent Models}

To study human carcinogenesis, animal models have been developed to reproduce human chronic inflammation associated with cholangiocarcinogenesis, and to induce or inhibit specific oncogenes or tumor-suppressor genes. Carcinogenesis models in CCA are divided into chemically induced mouse models and genetically engineered mouse models (GEMM).

\subsubsection{Chemically Induced Rodent Models}

Chemically induced rodent models represent one of the best tools for carcinogenesis study because they mimic both tumor induction and tumor progression. Animals develop tumors by the toxic effect of specific compounds that induce DNA damage. Several studies have shown CCA formation after administering diethylnitrosamine (DEN) in mice (Figure 2A), furan and thioacetamide (TAA) mainly in rats and, dimethylnitrosamine (DMN) in hamster models [146,147].

DEN, like many nitrosamines, is a potent carcinogen able to induce liver cancer [148]. Umemura et al. demonstrated that in mice DEN (administrated in the drinking water at 20 parts per millions (p.p.m.) for 8 weeks) in combination with pentachlorophenol, an environmental pollutant (at the concentrations of 1.2, 2.2 and $2.5 \mathrm{mg} /$ mouse/day for 23 weeks), promoted the formation of multifocal biliary cystic lesions and resulted in CCA development in a dose-dependent manner [149]. Proper chemically induced mouse models should better reflect the clinical background of CCA patients, such as the presence of chronic cholestasis, which has an active role in CCA onset due to the induction of genetic aberrations and pro-survival signaling pathways [146]. For this purpose, a recent model showed the tumorigenicity of intraperitoneal administration of DEN for 2 weeks prior to the left and 
median bile duct ligation (LMBDL), responsible for cholestasis, and DEN gavage once a week, 7 days after LDMB [150].

DMN is a potent carcinogen able to induce DNA alkylation and the production of reactive oxygen species, thus resulting in DNA damage [151]. In 1978, Thamavit et al. were the first to demonstrate the role of DMN in the induction of CCA in O. viverrini-infected hamster model. Briefly, hamsters first received an intragastric administration of $\mathrm{O}$. viverrini. After the detection of the eggs, DMN was added at $0.0025 \%$ in drinking water. The authors showed that all $\mathrm{O}$. viverrini-infected hamsters that received DMN developed CCA. In contrast, the group that received DMN alone and the animals only infected by O.viverrini did not develop the tumor [147].

Furan is a heterocyclic compound commonly used in animal models of liver cancer. In rats, chronic administration of $8 \mathrm{mg} / \mathrm{kg}$ furan by gavage in corn oil 5 days per week, for 15 months promoted CCA development as early as 9 months in $98 \%$ of the treated animals [152]. At higher doses (15-60 $\mathrm{mg} / \mathrm{kg} /$ per day), furan administration induced rapid development of cholangiofibrosis in the caudate liver lobe after 2-3 weeks of treatment; notably, cholangiofibrosis persisted until 6 weeks after treatment, thus mimicking the natural progression from chronic bile duct lesions to cholangiofibrosis to CCA development [153].

TAA is a potent hepatotoxin able to induce progressive damage of the biliary epithelium, starting from typical dysplasia and ultimately resulting in CCA development [154]. In rats, TAA $(0.03 \%$ in drinking water administrated for a 24-week period) induces hepatic fibrosis and cirrhosis; moreover it stimulates an inflammatory response in the bile ducts and an intense desmoplastic reaction, thus representing an excellent model to assess cholangiocarcinogenesis in vivo [155].

Chemically induced models are a useful tool to identify toxic compounds involved in CCA carcinogenesis. It should be noted that for a more detailed study, combining transgenic and chemically induced models could better clarify the mechanisms related to both tumor initiation and progression [156].

\subsubsection{Genetically Engineered Mouse Models (GEMM)}

Genetically engineered mouse models (GEMM) harbor the most frequent oncogenic alterations (activating mutations, deletion, loss of genes) observed in human CCA. GEMMs include transgenic and hydrodynamic transfection (HT) models (Figure 2B, C). Their strength is the spontaneous formation of tumors in immunocompetent mice with an active TME, closely reflecting the human clinical condition [146].

\subsubsection{Transgenic Models}

Transgenic animals are research models whose genome has been deliberately modified by introducing foreign DNA [157].

Three techniques are mainly used to create transgenic mice: (i) DNA delivery by retroviral vectors; (ii) microinjection of exogenous DNA into the pro-nuclei of fertilized one-cell embryos subsequently transferred into the oviduct of a pseudo-pregnant surrogate mother; and (iii) DNA introduction into embryonic stem cells (ES) derived from the inner cell mass of the blastocysts [157]. Currently, recombinant DNA technologies, such as the Cre-Lox P system, allow site- and time-specific targeting in the mouse.

The ideal transgenic model should ensure short tumor latency and the detection of metastases. In particular, CCA transgenic models should clearly show signs of inflammation or chronic liver injury before cancer development.

Several studies aimed at investigating the CCA genesis are based on transgenic mouse models that closely represent the human background of this tumor. Here, we describe their pros and cons, being conscious that the perfect CCA transgenic model does not exist yet.

$\mathrm{Xu}$ et al. described a model based on the conditional knockout of Smad and Pten, involved in the G1-S cell cycle arrest [158] and in cell proliferation and survival [159], respectively. Mice were affected 
by bile duct hyperplasia at 2 months of age, followed by iCCA development in 4-7 months. However, this model did not show any sign of chronic liver injury, inflammation, and metastases [160].

A recent report by Ikenoue et al. proposed a transgenic mouse model bearing an activating mutation of KRAS and a deletion of PTEN [161]. They demonstrated that 5-week-old transgenic mice started to develop CCA symptoms such as hemorrhagic ascites, abdominal distension secondary to hepatic enlargement, jaundice, and weight loss. The average life of mice was about 46 days and the autopsy showed several tumor nodules. Immunohistochemical analyses revealed that mice with one PTEN mutated allele had hepatocellular dysplasia with few nodules resembling iCCA, while PTEN WT mice developed only hepatocellular dysplasia, thus showing the importance of PTEN in cholangiocarcinogenesis. Unfortunately, even this model showed no inflammation or chronic liver injury before CCA development.

$\mathrm{O}^{\prime}$ Dell et al. generated a transgenic model with two of the most common gene aberrations, involved in CCA genesis (KRAS mutation and TP53 deletion) [162]. Nine-week-old transgenic mice with homozygous deletion of TP53 already showed tumor lesions, $66 \%$ of which were exclusively iCCA and $17 \%$ had a mixed CCA-HCC phenotype. Different from the previous models, tumors showed adjacent organ invasion and metastases. Unfortunately, also in this case, transgenic mice did not show signs of inflammation or chronic liver injury [162].

The model (IDH2-KRAS) generated by Saha et al. closely represented iCCA human background, since the gain of function of both IDH1 and IDH2, involved in hepatocyte differentiation, is present in $25 \%$ of patients $[24,48,163]$. The authors observed palpable liver tumors in $100 \%$ mice at $33-58$ weeks [48] and peritoneal metastases were detected. Subsequently, to deeply investigate the origin of the detected liver tumors, the authors performed histopathological analysis, demonstrating iCCA features by CK19 staining. However, tumor latency was long, making this model difficult to use.

Kiguchi et al. generated a model based on the constitutive expression in the liver of ERBB2 [164], often found in CCA patients. ERBB2 plays a pivotal role in proliferation and migration, as it activates the RAS-ERK and PI3K-Akt pathways [165]. They demonstrated that $85 \%$ of mice developed gallbladder adenocarcinoma at $2-3$ weeks of age and that $87 \%$ and $30 \%$ of mice developed common bile duct and intrahepatic bile duct tumors, respectively, starting from 4 months of age, thus making it primarily a model of gallbladder carcinoma. Also, in this case CCA latency was too long.

The model by Zender et al. proposed a liver-specific, constitutive expression of Notch [166], a key regulator of the biliary tree proliferation in embryogenesis and involved in CCA carcinogenesis [167]. Eight-month-old mice showed alterations in the nuclear morphology of liver cells and xenotransplantation into the flanks of immunodeficient mice caused the development of iCCA, as demonstrated by desmoplastic stroma and CK7 and CK17 expression. Anyway, the authors described an HCC-CCA mixed tumor phenotype. Hence, this cannot be considered a primary CCA model.

Farazi et al. established a model based on TP53 deletion; mice were treated with carbon tetrachloride $\left(\mathrm{CCl}_{4}\right)$, a liver fibrotic agent $(10 \mu \mathrm{L} / \mathrm{g}$ body weight of a $10 \%$ solution in olive oil by i.p. injection three times weekly for 4 months starting at 6 weeks). Initially, mice developed chronic liver injury with fibrosis and inflammation before iCCA genesis [168], and 5\% of the mice with a TP53 homozygous deletion (p53-/-) developed tumor [168]. Notably, the neoplastic lesions were embedded in a highly desmoplastic stroma, thus accurately reproducing the human disease [169]. Table 3 summarizes transgenic CCA mouse models, including both advantages and disadvantages. 
Table 3. CCA transgenic mouse models described in the literature.

\begin{tabular}{|c|c|c|c|c|c|}
\hline Name & Generation & Effects & Advantages & Disadvantages & References \\
\hline $\begin{array}{l}\text { Smad4-Pten } \\
\text { model }\end{array}$ & $\begin{array}{l}\text { Smadco and Ptenco } \\
\text { with Alb-cre mice. }\end{array}$ & $\begin{array}{l}\text { Bile duct } \\
\text { hyperplasia at } 2 \\
\text { months; } \\
\text { Tumor } \\
\text { development at } \\
4-7 \text { months }\end{array}$ & $\begin{array}{l}\text { Similar to human } \\
\text { iCCA }\end{array}$ & $\begin{array}{l}\text { Mixed HCC-CCA } \\
\text { phenotype; } \\
\text { No inflammation; } \\
\text { No chronic liver } \\
\text { injury; } \\
\text { No metastases }\end{array}$ & [170] \\
\hline $\begin{array}{l}\text { KRas-IDH } \\
\text { model }\end{array}$ & $\begin{array}{l}\text { Mutant IDH2 } \\
\text { (LSL-IDH2R172K), } \\
\text { mice with } \\
\text { activating KRAS } \\
\text { mutation } \\
\text { (LSL-KrasG12) } \\
\text { with Alb-Cre mice. }\end{array}$ & $\begin{array}{l}\text { Palpable liver } \\
\text { tumors at } 33-58 \\
\text { weeks }\end{array}$ & $\begin{array}{l}\text { Peritoneal metastases; } \\
\text { Similar to human } \\
\text { iCCA }\end{array}$ & Long latency time & [48] \\
\hline $\begin{array}{l}\text { KRas-Pten } \\
\text { model }\end{array}$ & $\begin{array}{l}\text { Mice carrying a } \\
\text { specific mutation } \\
\text { of KRAS } \\
\text { (LSL-KrasG12D) } \\
\text { and/or a Ptenflox } \\
\text { with Alb-Cre+ } \\
\text { mice. }\end{array}$ & $\begin{array}{l}\text { Multiple tumor } \\
\text { nodules }\end{array}$ & $\begin{array}{l}\text { Similar to human } \\
\text { iCCA; } \\
\text { Short tumor latency }\end{array}$ & $\begin{array}{l}\text { No chronic liver } \\
\text { injury; } \\
\text { No metastases. } \\
\text { No inflammation }\end{array}$ & [161] \\
\hline $\begin{array}{l}\text { KRas-P53 } \\
\text { model }\end{array}$ & $\begin{array}{l}\text { Alb-Cre mutants } \\
\text { with KrasG12D } \\
\text { mice with or } \\
\text { without deletion of } \\
\text { tumor protein } 53 .\end{array}$ & $\begin{array}{l}\text { Tumors } \\
\text { develop at } 9 \\
\text { weeks of age }\end{array}$ & $\begin{array}{l}\text { Adjacent organ } \\
\text { invasion; } \\
\text { Distant metastases }\end{array}$ & $\begin{array}{l}\text { No chronic liver } \\
\text { injury; } \\
\text { No stromal } \\
\text { No inflammation; }\end{array}$ & [162] \\
\hline $\begin{array}{l}\text { ErbB-2A } \\
\text { model }\end{array}$ & $\begin{array}{l}\text { Bovine Keratin } 5 \\
\text { (BK5) promoter in } \\
\text { mice with } \\
\text { constitutive } \\
\text { expression of } \\
\text { ErbB2. }\end{array}$ & $\begin{array}{l}\text { Gallbladder } \\
\text { carcinoma at } \\
\text { 2-3 weeks;Bile } \\
\text { duct carcinoma } \\
\text { and iCCA at } 4 \\
\text { months }\end{array}$ & $\begin{array}{l}\text { Similar to human } \\
\text { iCCA }\end{array}$ & $\begin{array}{l}\text { Gallbladder } \\
\text { carcinoma model; } \\
\text { Long latency time }\end{array}$ & [164] \\
\hline Notch1 model & $\begin{array}{l}\text { Mice with } \\
\text { overexpression of } \\
\text { intracellular } \\
\text { domain of Notch } 1 \\
\text { (NICD) } \\
\text { (Rosa26Notch1C) } \\
\text { with Alb-Cre mice. }\end{array}$ & $\begin{array}{l}\text { Changes in } \\
\text { nuclear } \\
\text { morphology at } \\
8 \text { months. }\end{array}$ & $\begin{array}{l}\text { iCCA after } \\
\text { xenotransplantation of } \\
\text { malignant cells. }\end{array}$ & $\begin{array}{l}\text { Probably mixed } \\
\text { HCC-CCA } \\
\text { phenotype due to } \\
\text { the high plasticity } \\
\text { of the transformed } \\
\text { cells. }\end{array}$ & [166] \\
\hline $\begin{array}{l}\text { P53-/- CCL4 } \\
\text { model }\end{array}$ & $\begin{array}{l}\text { CCL4 in p53 } \\
\text { deleted mice }\end{array}$ & $\begin{array}{l}\text { Fibrosis with } \\
\text { cholangiocyte } \\
\text { proliferation; } \\
\text { iCCA } \\
\text { development in } \\
54 \% \text { of mice. }\end{array}$ & $\begin{array}{l}\text { Chronic liver injury } \\
\text { with fibrosis and } \\
\text { inflammation. }\end{array}$ & $\begin{array}{l}\text { Development of } \\
\text { HCC; } \\
\text { Long treatment } \\
\text { with CCL4 }\end{array}$ & [170] \\
\hline
\end{tabular}

Although these models reflect clinical conditions better than other models [146], they are very expensive and time-consuming. Furthermore, it should be noted that transgenes may have different expression levels than expected by means of amount and site of integration [171].

\subsubsection{Hydrodynamic Transfection for Generation of Mouse Models}

Hydrodynamic transfection (HT) is a technique used for delivering DNA, RNA, proteins, and synthetic compounds to different tissues in rats, mice, dogs, and primates. Due to its high efficiency, feasibility, versatility, and safety, and its few transient side effects, HT is a promising alternative to other techniques, such as germ-line knockout or transgenic mice [172]. HT consists of a rapid tail-vein injection of a large volume ( $10 \%$ of body weight) [173] of the delivery solution, (such as 
Saline solution [174], Ringers solution [175,176], and Phosphate-Buffered Saline solution $[177,178])$ and, exploiting the consequent cardiac congestion and the hydrodynamic pressure in the inferior vena cava, the solution is pushed back to the liver and kidneys through the hepatic and renal vein, respectively. This pressure enlarges the pores of the fenestrated endothelium of the liver and acts on hepatocytes that are closely associated with capillaries. The membrane pores lock after injection, and the solution is entrapped inside the cells. The transfection is efficient in kidneys, spleen, lungs, and heart, but mainly in the liver, where approximately $10-40 \%$ of hepatocytes can be transfected, predominantly the cells in the peri-central region [172,179]. To overcome the rapid degradation of transfected genes, HT is used in combination with the sleeping beauty (SB) transposase that binds to specific inverted repeats and inserts said transposase at a new location in a TA dinucleotide. The HT technique is very versatile; in fact, it can be combined with other techniques, such as CRISPR-Cas9 editing [180], and it can be considered a good tool for clarifying the main players involved in CCA genesis (Figure 2C).

Among the models described in the literature, Carlson et al. [181] demonstrated that NRAS expression through HT resulted in the development of CCA nodular tumors after 4-6 weeks in $\mathrm{Arf}^{-/-}$ mice and after twice as long in $\mathrm{Arf}^{+/-}$mice, thus confirming the already known tumor suppressive role of Arf in CCA [182]. The time required for tumorigenesis was reduced to 3-4 weeks when a constitutively activated form of AKT, implicated in cell survival and growth, was expressed in combination with NRAS, revealing also its importance in the development of iCCA [173].

Wang et al. investigated the role of Notch cascade in CCA pathogenesis by using an already established HT models of overexpressed activated forms of v-akt murine thymoma viral oncogene homolog (myr-AKT) and yes-associated protein (YapS127A) genes in hepatocytes (AKT/Yap) [183]. This previous work demonstrated that AKT/Yap-induced iCCA originate from mature hepatocyte. Unfortunately, the authors did not clarify trans-differentiation mechanisms. In this regard, Wang et al. explored the role of Notch cascade in AKT/Yap iCCA tumors. The authors confirmed that the Notch signaling pathway is activated in iCCA: in particular Notch2 is the main influencer, whereas inactivation of Notch1 slightly delays tumor development [184].

The key advantages of GEMMs consist in reproducing specific genetic aberrations identified in human tumors, and in following cancer development from its early stage. Nonetheless, in GEMM models, tumor development is slow and variable, delaying the possibility of testing therapeutic strategies. For this purpose, in order to aid the development and examination of new therapeutic responses, other mouse models, described below, are used [185].

\subsection{Experimental Mouse Models to Investigate Therapeutic Approaches in CCA}

Orthotopic and/or human tumor xenografts represent excellent models to explore cancer-related mechanisms, to identify novel therapeutic approaches, and to predict drug responses [135].

Cancer studies in vitro are commonly corroborated by in vivo tumor graft models (Figure 2D,E). Currently, it is possible to develop several kinds of grafts. Briefly, xenograft is defined as the transplantation of tissue or cells derived from a different species into an immunodeficient animal host; allograft, instead, is the transplantation of tissue or cells derived from the same species of the immunocompetent animal model [186].

\subsubsection{Ectopic Xenotransplantation Models of CCA}

In oncology, xenografts represent a model of heterotopic graft obtained by the subcutaneous injection of human cells or tissue into the flank of immunodeficient or nude mice.

In 1985, for the first time, a human CCA cell line (SLU-132) was successfully implanted into the flank of a mouse to study the efficacy of novel anti-cancer drugs (Figure 2D) [187]. Following the success of this ectopic xenograft model of CCA, other studies have exploited cell lines derived from different CCA histotypes to investigate CCA tumorigenesis and to explore responses and safety of new therapeutic strategies. Xenograft models are advantageous because they recapitulate the genetic and epigenetic abnormalities of human tumors; moreover, they are reproducible, cost-efficient, and require 
short experimental times. On the other hand, a drawback of xenografts is the unfeasibility to study the crosstalk between tumors (human-derived) and the host microenvironment (murine-derived); furthermore, the site of implantation is unphysiological and rarely metastatic [188].

Ectopic xenograft models have pioneered the in vivo investigations focused on testing the antitumor efficacy of new therapeutic compounds (e.g., chemotherapeutic agents, targeted therapy, drug combinations) [32,54,189-198] (Figure 2D). To date, xenograft models have been obtained by the injection of 2-5 $\times 10^{6}$ suspended cells of different iCCA (e.g., HuCC-T1 and CC-LP-1) and eCCA (e.g., QBC939 and Sk-ChA-1) cell lines, with a tumor engraftment rate close to $100 \%$ and a latency of about two weeks [188]. A secondary application is the study of the role of proteins, mRNA, and non-coding RNAs on tumor biology. Recently, a novel model of a CCA xenotransplant was performed using Tet-on microRNA 21 (miR-21) organoids derived from a liver biopsy of chemoresistant iCCA. Mice were treated with a HSP90 inhibitor, or vehicle, while changes in their diet were applied to modulate the expression of miR-21. After 2 weeks of treatment, the mice were randomized to continue on doxycycline-supplemented diet or subjected to a doxycycline-free diet. The mice on doxycycline-free diet achieved a significantly better tumor response than those kept on a doxycycline diet, suggesting that miR-21, commonly overexpressed in tumors, has a role in the resistance to HSP90 inhibitors [137]. In another study, $5 \times 10^{6}$ iCCA cells (CCLP1) transduced with a lentiviral vector carrying the pre-miR-144 were xenografted in nude mice. After 5 weeks, tumor growth was suppressed, leading to p-AKT downregulation and direct targeting of LIS1, a protein regulator involved in cancer proliferation [199]. Using a similar approach, Ursu et al. demonstrated that after 6 weeks tumor growth was significantly suppressed in mice subcutaneously injected with $1 \times 10^{6} \mathrm{CCA}$ cells $(\mathrm{KMCH})$ stably expressing miR-876, with a mechanism involving the overexpression of the antiapoptotic gene BCL-XL [200].

In summary, these studies demonstrate the reproducibility of ectopic xenograft models, characterized by simple experimental protocols and by lack of adverse effects. Furthermore, using xenograft models, it is possible to monitor the real tumor growth by measuring the mass volume. Nevertheless, because the tumor is implanted in an ectopic site, the milieu is unphysiological and therefore not optimal to study CCA biology.

\subsubsection{Orthotopic Mouse Models}

Orthotopic xenograft models accurately mimic the tumor milieu, favoring tumor dissemination through spontaneous metastasis. Moreover, orthotopic models allow a more realistic therapeutic outcome, fostering an adequate drug biodistribution [201]. Immunocompetent mice are used for syngeneic orthotopic implantation; they are provided with an endogenous immune system, which is crucial for immunotherapy studies in terms of the identification of therapeutic targets and predictive and prognostic factors [202]. At the same time, since there are peculiar differences between mouse and human immune systems (e.g., signaling pathways in T cells, receptor expression in immune cells, and antigen processing and presentation machinery) [203], several improvements have been introduced in mouse models to increase their heterogeneity and to better mirror human cancer milieu.

Intrahepatic engraftment is performed using two methods; the first one consists in injecting CCA cells into the portal or splenic vein of mice, and the second one consists in the direct injection into the liver parenchyma through the capsule (Figure 2E). Rizvi et al., for the first time, implanted CCA mouse cell lines into the medial lobe of mouse livers and observed orthotopic syngeneic tumor formation. The resulting tumors reflected the histopathologic characteristics typically found in human iCCA, including desmoplasia and expression of CK-19 and SRY box 9 (SOX9) [204]. Currently, this is the only CCA syngeneic mouse model available, underlying the complexity and the limitations of such models in the CCA setting. In recent studies, eCCA cell lines (EGI-1 and TFK-1 cells) expressing luciferase were transplanted into the liver through intrasplenic injection. However, these cells also engrafted into the spleen in addition to the liver [205]. Using this approach, Cadamuro et al. showed that low-dose metronomic paclitaxel treatment decreased lung dissemination of EGI-1 cells without significantly 
affecting their local tumor growth [206]. Erice et al. performed an orthotopic model implanting small fragments of eCCA tumor derived from EGI-1 cells previously grown subcutaneously. After monitoring tumor implantation by magnetic resonance imaging, mice were randomized to receive a diet with an agonist (Obeticholic Acid) of the bile acid receptor, which inhibited tumor growth compared to the control group [207]. Interestingly, spheroids developed from CSCs immunosorted from human CCA primary cells (approximately $1 \times 10^{5}$ cells) and intrahepatically injected developed tumor masses only in mouse models of liver cirrhosis within 4 months; moreover, these tumors displayed epithelial traits reproducing the original human iCCA [120]. More recently, a minimally invasive ultrasound-guided intrahepatic injection was established. Due to its nominally invasive nature, this method decreases the risks of surgical complications and provides a potential experimental tool for future screening of cancer therapeutics in orthotopic models [208].

Although orthotopic implantations are an impressive tool to conduct investigations focused on the TME and tumor progression, their development requires a long period, the study of tumor spreading is laborious, and it is based on imaging tools or on animal euthanasia [146].

\subsubsection{Patient-Derived Xenograft (PDX)}

PDX models are currently used to study tumor biology and to test personalized therapies. In this approach, tumor fragments derived from biopsies or surgical specimens are directly implanted into the dorsal region (subcutaneous implantation) or target organs (orthotopic implantation) of immunodeficient mice [209]. PDX retain the main traits of tumor bulk, including the surrounding stroma, 3D architecture, and tumor heterogeneity (Figure 2D), thus providing a powerful and reliable tool for predicting the therapeutic response in different types of solid cancers [210-212].

Recently, several groups successfully obtained PDX models of iCCA. The first was generated by Cavalloni et al., who established a KRAS-mutant CCA PDX model that faithfully recapitulates the histologic, genetic, immunogenetic, and transcriptomic profiles of the parental tumor [56]. This model was also used to test the in vivo efficacy of trabectedin and its role in deregulating RNA transcripts involved in cell adhesion, stress-related response, and in pathways involved in cholangiocarcinogenesis [213,214]. A second iCCA PDX model, endogenously expressing the FGFR2-CCDC6 fusion protein was employed to show the ability of the FGFR inhibitors ponatinib, dovitinib and BGJ398 to modulate FGFR signaling and inhibit tumor growth [215]. Moreover, Saha et al. created iCCA PDX models bearing an IDH mutation, frequently present in CCA, demonstrating a pronounced efficacy of dasatinib, a multi-tyrosine kinase inhibitor [216]. Another group demonstrated that the treatment of iCCA PDX models with a pan-FGFR inhibitor was associated with a decrease of tumor size and necrosis [217]. Garcia et al. showed that JQ1, a bromodomain and extra-domain inhibitor, suppressed tumor growth in both an iCCA and an eCCA PDX models, inhibiting c-Myc expression [218]. A study published last year showed that a selective Notch1 inhibitor switched off the Notch pathway and reduced tumor growth to the same extent of GEM in iCCA PDXs [219].

Although many CCA PDX have been established, derived from both iCCA and eCCA, only a few have been molecularly and genetically characterized. Table 4 shows some of PDX models, of which at least one molecular/genetic characteristic is known.

Unfortunately, PDX models have some crucial limitations. Firstly, the variability in the success of engraftment rate is significantly different depending on both the primary tumor itself (presence of necrotic tissue, time from surgery, and tumor engraftment and aggressiveness) and the manipulation ability in different laboratories (internal organization, different protocols for treating surgical samples, etc.). Finally, another strong limitation is the long period required for engraftment, frequently up to several months. This prolonged time should be considered as a negative factor when PDX models would be used as "Avatars" for therapy personalization. 
Table 4. Representative and characterized CCA patient-derived xenograft (PDX) models.

\begin{tabular}{|c|c|c|c|}
\hline Tumor Type & Mice & Molecular Characterization & References \\
\hline iCCA & NOD/SCID & K-Ras mutation & [56] \\
\hline iCCA & NSG & FGFR2-CCDC6 gene fusion & [215] \\
\hline iCCA & NGS & DH1 R132C mutation & [216] \\
\hline iCCA & NOD/SCID & $\begin{array}{c}\text { Constitutive expression of FGFR } \\
1-4 \text { mRNA and FRS2 }\end{array}$ & [217] \\
\hline iCCA & CD1 immunodeficient nude & NOTCH1 overexpression & [219] \\
\hline iCCA & $\begin{array}{l}\text { B-NDG miceBALB/c (nu/nu) } \\
\text { nude }\end{array}$ & CDK7 overexpression & [220] \\
\hline iCCA & NOD/SCID & YAP overexpression & [204] \\
\hline iCCA & Balb/c RJ mice & Oct- $3 / 4$ or Sox 2 expression & [60] \\
\hline iCCA & NOD/SCID & $\begin{array}{l}\text { Sodium-dependent vitamin C } \\
\text { transporter } 2 \text { (SVCT-2) expression }\end{array}$ & [221] \\
\hline eCCA & Balb/c RJ mice & Oct- $3 / 4$ or Sox 2 expression & [60] \\
\hline
\end{tabular}

\section{Conclusions and Future Perspectives}

Here, we have detailed the different preclinical models available for CCA studies. In the last decades, many improvements have been made; in vitro and in vivo models have achieved extensive progresses and have increased their complexity and reliability. However, all the models have advantages and drawbacks (Table 5); to date, 2D cell lines and mice xenografts, the most frequently used tools, remain the first step for all preclinical investigations, even with their well-known limits. All these models should be singularly exploited to improve our knowledge of this disease, from early onset to tailored therapies, but they are not completely representative of the human tumor. Creating a preclinical model to fully recapitulate all the tumor conditions is the new challenge.

In particular, "ideal" animal models should be developed and fully characterized, accounting for the CCA site of origin and sub-classification, their stem cell origin, and genetic, epigenetic, and molecular alterations. The various predisposing risk factors make CCA a heterogeneous malignancy. It is mandatory to develop models that recapitulate, for example, precancerous lesions due to chronic damage (e.g., chronic cholestasis, cirrhosis, primary sclerosing cholangitis, HCV and HBV infections, and steatosis), in order to investigate the disease from its origin to its progression. Furthermore, it is mandatory to standardize the CCA classification, in particular iCCA subgroups (small and large duct types), taking into account the recent WHO classification of digestive system tumors, and data relating to the differences on their genetic and molecular profiles, which reflect the diversity in terms of clinical pathological features. Failure to observe the iCCA classification could represent a limitation of current CCA preclinical models, therefore, the scientific community should adapt to the new guidelines. It is also necessary to analyze the role played by the desmoplastic stroma, characteristic of CCA, in the response to therapies. Finally, the TME, including the immune system, needs to be further explored. In recent years, immunotherapy has become increasing popular, giving encouraging results in some tumors. The creation of suitable immunocompetent models of CCA would allow to deepen the role of the immune system in the antitumor response and to investigate the applicability of immunotherapy in CCA patients to improve survival. In addition, the generation of new models of chemo/targeted therapy resistance could allow a better understanding of the mechanisms underlying drug resistance. Due to the rarity of the disease, the collaboration of the CCA scientific community is essential to accelerate this milestone. 
Table 5. Advantages and disadvantages of in vitro and in vivo CCA experimental models.

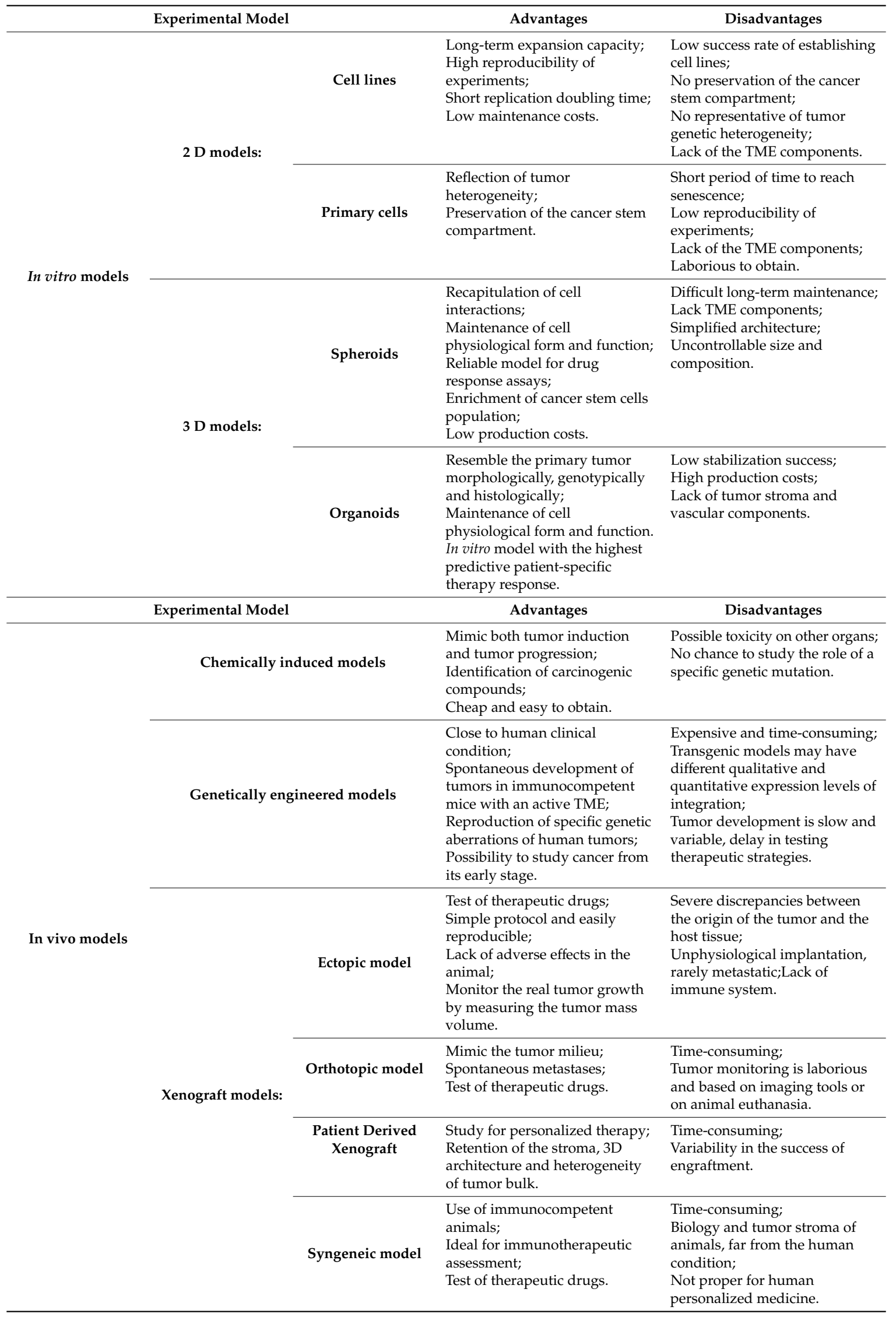


Author Contributions: A.M., C.V., F.V., S.T., C.P.-N., A.R., G.C.: Writing, editing and preparation of figures. G.B., M.A.: Revision and critical discussion. All authors have read and have approved the final manuscript.

Funding: This research was funded by Italian Ministry of Health-Ricerca Corrente 2020, FPRC 5xmille 2015 Ministero Salute "Cancer Im-Gen" and Fondazione Roche-Bando per la ricerca 2019 to AM.

Acknowledgments: We thank Radika Srinivasan for the linguistic revision.

Conflicts of Interest: The authors declare no conflict of interest.

\section{References}

1. Moazzami, B.; Majidzadeh-A, K.; Dooghaie-Moghadam, A.; Eslami, P.; Razavi-Khorasani, N.; Iravani, S.; Khoshdel, A.; Shahi, F.; Dashti, H.; Mehrvar, A.; et al. Cholangiocarcinoma: State of the Art. J. Gastrointest Cancer 2020. [CrossRef] [PubMed]

2. Razumilava, N.; Gores, G.J. Cholangiocarcinoma. Lancet 2014, 383, 2168-2179. [CrossRef]

3. Forner, A.; Vidili, G.; Rengo, M.; Bujanda, L.; Ponz-Sarvisé, M.; Lamarca, A. Clinical presentation, diagnosis and staging of cholangiocarcinoma. Liver Int. 2019, 39 (Suppl. 1), 98-107. [CrossRef] [PubMed]

4. Nagtegaal, I.D.; Odze, R.D.; Klimstra, D.; Paradis, V.; Rugge, M.; Schirmacher, P.; Washington, K.M.; Carneiro, F.; Cree, I.A.; WHO Classification of Tumours Editorial Board. The 2019 WHO classification of tumours of the digestive system. Histopathology 2020, 76, 182-188. [CrossRef] [PubMed]

5. Khan, S.A.; Tavolari, S.; Brandi, G. Cholangiocarcinoma: Epidemiology and risk factors. Liver Int. 2019, 39 (Suppl. 1), 19-31. [CrossRef]

6. Khan, S.A.; Davidson, B.R.; Goldin, R.D.; Heaton, N.; Karani, J.; Pereira, S.P.; Rosenberg, W.M.; Tait, P.; Taylor-Robinson, S.D.; Thillainayagam, A.V.; et al. Guidelines for the diagnosis and treatment of cholangiocarcinoma: An update. Gut 2012,61, 1657-1669. [CrossRef]

7. Alsaleh, M.; Leftley, Z.; Barbera, T.A.; Sithithaworn, P.; Khuntikeo, N.; Loilome, W.; Yongvanit, P.; Cox, I.J.; Chamodol, N.; Syms, R.R.; et al. Cholangiocarcinoma: A guide for the nonspecialist. Int. J. Gen. Med. 2019, 12, 13-23. [CrossRef]

8. Turgeon, M.K.; Maithel, S.K. Cholangiocarcinoma: A site-specific update on the current state of surgical management and multi-modality therapy. Chin. Clin. Oncol. 2020, 9, 4. [CrossRef]

9. Valle, J.W.; Furuse, J.; Jitlal, M.; Beare, S.; Mizuno, N.; Wasan, H.; Bridgewater, J.; Okusaka, T. Cisplatin and gemcitabine for advanced biliary tract cancer: A meta-analysis of two randomised trials. Ann. Oncol. 2014, 25, 391-398. [CrossRef]

10. Ulahannan, S.V.; Rahma, O.E.; Duffy, A.G.; Makarova-Rusher, O.V.; Kurtoglu, M.; Liewehr, D.J.; Steinberg, S.M.; Greten, T.F. Identification of active chemotherapy regimens in advanced biliary tract carcinoma: A review of chemotherapy trials in the past two decades. Hepat. Oncol. 2015, 2, 39-50. [CrossRef]

11. Yang, R.; Wang, B.; Chen, Y.J.; Li, H.B.; Hu, J.B.; Zou, S.Q. Efficacy of gemcitabine plus platinum agents for biliary tract cancers: A meta-analysis. Anticancer Drugs 2013, 24, 871-877. [CrossRef] [PubMed]

12. Weigt, J.; Malfertheiner, P. Cisplatin plus gemcitabine versus gemcitabine for biliary tract cancer. Expert Rev. Gastroenterol. Hepatol. 2010, 4, 395-397. [CrossRef] [PubMed]

13. Marin, J.J.G.; Lozano, E.; Herraez, E.; Asensio, M.; Di Giacomo, S.; Romero, M.R.; Briz, O.; Serrano, M.A.; Efferth, T.; Macias, R.I.R. Chemoresistance and chemosensitization in cholangiocarcinoma. Biochim. Biophys. Acta Mol. Basis Dis. 2018, 1864, 1444-1453. [CrossRef] [PubMed]

14. Sahu, S.; Sun, W. Targeted therapy in biliary tract cancers-current limitations and potentials in the future. J. Gastrointest Oncol. 2017, 8, 324-336. [CrossRef] [PubMed]

15. Abou-Alfa, G.K.; Sahai, V.; Hollebecque, A.; Vaccaro, G.; Melisi, D.; Al-Rajabi, R.; Paulson, A.S.; Borad, M.J.; Gallinson, D.; Murphy, A.G.; et al. Pemigatinib for previously treated, locally advanced or metastatic cholangiocarcinoma: A multicentre, open-label, phase 2 study. Lancet Oncol. 2020, 21, 671-684. [CrossRef]

16. Domcke, S.; Sinha, R.; Levine, D.A.; Sander, C.; Schultz, N. Evaluating cell lines as tumour models by comparison of genomic profiles. Nat. Commun. 2013, 4, 2126. [CrossRef]

17. Ertel, A.; Verghese, A.; Byers, S.W.; Ochs, M.; Tozeren, A. Pathway-specific differences between tumor cell lines and normal and tumor tissue cells. Mol. Cancer 2006, 5, 55. [CrossRef]

18. Gillet, J.P.; Calcagno, A.M.; Varma, S.; Marino, M.; Green, L.J.; Vora, M.I.; Patel, C.; Orina, J.N.; Eliseeva, T.A.; Singal, V.; et al. Redefining the relevance of established cancer cell lines to the study of mechanisms of clinical anti-cancer drug resistance. Proc. Natl. Acad. Sci. USA 2011, 108, 18708-18713. [CrossRef] 
19. Yamaguchi, N.; Morioka, H.; Ohkura, H.; Hirohashi, S.; Kawai, K. Establishment and characterization of the human cholangiocarcinoma cell line HChol-Y1 in a serum-free, chemically defined medium. J. Natl. Cancer Inst. 1985, 75, 29-35.

20. Farshidfar, F.; Zheng, S.; Gingras, M.C.; Newton, Y.; Shih, J.; Robertson, A.G.; Hinoue, T.; Hoadley, K.A.; Gibb, E.A.; Roszik, J.; et al. Integrative Genomic Analysis of Cholangiocarcinoma Identifies Distinct IDH-Mutant Molecular Profiles. Cell Rep. 2017, 19, 2878-2880. [CrossRef]

21. Jusakul, A.; Cutcutache, I.; Yong, C.H.; Lim, J.Q.; Huang, M.N.; Padmanabhan, N.; Nellore, V.; Kongpetch, S.; Ng, A.W.T.; Ng, L.M.; et al. Whole-Genome and Epigenomic Landscapes of Etiologically Distinct Subtypes of Cholangiocarcinoma. Cancer Discov. 2017, 7, 1116-1135. [CrossRef]

22. Zou, S.; Li, J.; Zhou, H.; Frech, C.; Jiang, X.; Chu, J.S.; Zhao, X.; Li, Y.; Li, Q.; Wang, H.; et al. Mutational landscape of intrahepatic cholangiocarcinoma. Nat. Commun. 2014, 5, 5696. [CrossRef]

23. Nakamura, H.; Arai, Y.; Totoki, Y.; Shirota, T.; Elzawahry, A.; Kato, M.; Hama, N.; Hosoda, F.; Urushidate, T.; Ohashi, S.; et al. Genomic spectra of biliary tract cancer. Nat. Genet. 2015, 47, 1003-1010. [CrossRef] [PubMed]

24. Borger, D.R.; Tanabe, K.K.; Fan, K.C.; Lopez, H.U.; Fantin, V.R.; Straley, K.S.; Schenkein, D.P.; Hezel, A.F.; Ancukiewicz, M.; Liebman, H.M.; et al. Frequent mutation of isocitrate dehydrogenase (IDH)1 and IDH2 in cholangiocarcinoma identified through broad-based tumor genotyping. Oncologist 2012, 17, 72-79. [CrossRef] [PubMed]

25. Arai, Y.; Totoki, Y.; Hosoda, F.; Shirota, T.; Hama, N.; Nakamura, H.; Ojima, H.; Furuta, K.; Shimada, K.; Okusaka, T.; et al. Fibroblast growth factor receptor 2 tyrosine kinase fusions define a unique molecular subtype of cholangiocarcinoma. Hepatology 2014, 59, 1427-1434. [CrossRef] [PubMed]

26. Akita, M.; Sofue, K.; Fujikura, K.; Otani, K.; Itoh, T.; Ajiki, T.; Fukumoto, T.; Zen, Y. Histological and molecular characterization of intrahepatic bile duct cancers suggests an expanded definition of perihilar cholangiocarcinoma. HPB (Oxford) 2019, 21, 226-234. [CrossRef] [PubMed]

27. Lau, D.K.; Mouradov, D.; Wasenang, W.; Luk, I.Y.; Scott, C.M.; Williams, D.S.; Yeung, Y.H.; Limpaiboon, T.; Iatropoulos, G.F.; Jenkins, L.J.; et al. Genomic Profiling of Biliary Tract Cancer Cell Lines Reveals Molecular Subtypes and Actionable Drug Targets. IScience 2019, 21, 624-637. [CrossRef]

28. Homma, S.; Nagamori, S.; Fujise, K.; Yamazaki, K.; Hasumura, S.; Sujino, H.; Matsuura, T.; Shimizu, K.; Kameda, H.; Takaki, K. Human bile duct carcinoma cell line producing abundant mucin in vitro. Gastroenterol. Jpn. 1987, 22, 474-479. [CrossRef]

29. Kusaka, Y.; Tokiwa, T.; Sato, J. Establishment and characterization of a cell line from a human cholangiocellular carcinoma. Res. Exp. Med. (Berl.) 1988, 188, 367-375. [CrossRef]

30. Yeung, Y.; Lau, D.K.; Chionh, F.; Tran, H.; Tse, J.W.T.; Weickhardt, A.J.; Nikfarjam, M.; Scott, A.M.; Tebbutt, N.C.; Mariadason, J.M. K-Ras mutation and amplification status is predictive of resistance and high basal pAKT is predictive of sensitivity to everolimus in biliary tract cancer cell lines. Mol. Oncol. 2017, 11, 1130-1142. [CrossRef]

31. Pignochino, Y.; Sarotto, I.; Peraldo-Neia, C.; Penachioni, J.Y.; Cavalloni, G.; Migliardi, G.; Casorzo, L.; Chiorino, G.; Risio, M.; Bardelli, A.; et al. Targeting EGFR/HER2 pathways enhances the antiproliferative effect of gemcitabine in biliary tract and gallbladder carcinomas. BMC Cancer 2010, 10, 631. [CrossRef] [PubMed]

32. Cavalloni, G.; Peraldo-Neia, C.; Varamo, C.; Chiorino, G.; Sassi, F.; Aglietta, M.; Leone, F. Preclinical activity of EGFR and MEK1/2 inhibitors in the treatment of biliary tract carcinoma. Oncotarget 2016, 7, 52354-52363. [CrossRef] [PubMed]

33. Katoh, H.; Shinbo, T.; Otagiri, H.; Saitoh, M.; Saitoh, T.; Ishizawa, S.; Shimizu, T.; Satoh, A.; Tazawa, K.; Fujimaki, M. Character of a human cholangiocarcinoma CHGS, serially transplanted to nude mice. Hum. Cell 1988, 1, 101-105. [PubMed]

34. Miyagiwa, M.; Ichida, T.; Tokiwa, T.; Sato, J.; Sasaki, H. A new human cholangiocellular carcinoma cell line (HuCC-T1) producing carbohydrate antigen 19/9 in serum-free medium. In Vitro Cell. Dev. Biol. 1989, 25, 503-510. [CrossRef] [PubMed]

35. Parasramka, M.; Yan, I.K.; Wang, X.; Nguyen, P.; Matsuda, A.; Maji, S.; Foye, C.; Asmann, Y.; Patel, T. BAP1 dependent expression of long non-coding RNA NEAT-1 contributes to sensitivity to gemcitabine in cholangiocarcinoma. Mol. Cancer 2017, 16, 22. [CrossRef] 
36. Goyal, L.; Shi, L.; Liu, L.Y.; Fece de la Cruz, F.; Lennerz, J.K.; Raghavan, S.; Leschiner, I.; Elagina, L.; Siravegna, G.; Ng, R.W.S.; et al. TAS-120 Overcomes Resistance to ATP-Competitive FGFR Inhibitors in Patients with FGFR2 Fusion-Positive Intrahepatic Cholangiocarcinoma. Cancer Discov. 2019, 9, 1064-1079. [CrossRef]

37. Vaquero, J.; Lobe, C.; Tahraoui, S.; Clapéron, A.; Mergey, M.; Merabtene, F.; Wendum, D.; Coulouarn, C.; Housset, C.; Desbois-Mouthon, C.; et al. The IGF2/IR/IGF1R Pathway in Tumor Cells and Myofibroblasts Mediates Resistance to EGFR Inhibition in Cholangiocarcinoma. Clin. Cancer Res. 2018, 24, 4282-4296. [CrossRef]

38. Wang, C.; Ye, H.; Zhang, L.; Cheng, Y.; Xu, S.; Zhang, P.; Zhang, Z.; Bai, J.; Meng, F.; Zhong, L.; et al. Enhanced expression of ten-eleven translocation 1 reverses gemcitabine resistance in cholangiocarcinoma accompanied by a reduction in P-glycoprotein expression. Cancer Med. 2019, 8, 990-1003. [CrossRef]

39. Storto, P.D.; Saidman, S.L.; Demetris, A.J.; Letessier, E.; Whiteside, T.L.; Gollin, S.M. Chromosomal breakpoints in cholangiocarcinoma cell lines. Genes Chromosomes Cancer 1990, 2, 300-310. [CrossRef]

40. Sirisinha, S.; Tengchaisri, T.; Boonpucknavig, S.; Prempracha, N.; Ratanarapee, S.; Pausawasdi, A. Establishment and characterization of a cholangiocarcinoma cell line from a Thai patient with intrahepatic bile duct cancer. Asian Pac. J. Allergy Immunol. 1991, 9, 153-157.

41. Intuyod, K.; Saavedra-García, P.; Zona, S.; Lai, C.F.; Jiramongkol, Y.; Vaeteewoottacharn, K.; Pairojkul, C.; Yao, S.; Yong, J.S.; Trakansuebkul, S.; et al. FOXM1 modulates 5-fluorouracil sensitivity in cholangiocarcinoma through thymidylate synthase (TYMS): Implications of FOXM1-TYMS axis uncoupling in 5-FU resistance. Cell Death Dis. 2018, 9, 1185. [CrossRef] [PubMed]

42. Iemura, A.; Maruiwa, M.; Yano, H.; Kojiro, M. A new human cholangiocellular carcinoma cell line (KMC-1). J. Hepatol. 1992, 15, 288-298. [CrossRef]

43. Komuta, M. A new classification of primary liver carcinomas based on their possible cellular origin. J. Hepatol. 2013, 58, S266. [CrossRef]

44. Shimizu, Y.; Demetris, A.J.; Gollin, S.M.; Storto, P.D.; Bedford, H.M.; Altarac, S.; Iwatsuki, S.; Herberman, R.B.; Whiteside, T.L. Two new human cholangiocarcinoma cell lines and their cytogenetics and responses to growth factors, hormones, cytokines or immunologic effector cells. Int. J. Cancer 1992, 52, 252-260. [CrossRef] [PubMed]

45. Asukai, K.; Kawamoto, K.; Eguchi, H.; Konno, M.; Asai, A.; Iwagami, Y.; Yamada, D.; Asaoka, T.; Noda, T.; Wada, H.; et al. Micro-RNA-130a-3p Regulates Gemcitabine Resistance via PPARG in Cholangiocarcinoma. Ann. Surg. Oncol. 2017, 24, 2344-2352. [CrossRef]

46. Yano, H.; Iemura, A.; Haramaki, M.; Momosaki, S.; Ogasawara, S.; Higaki, K.; Kojiro, M. A human combined hepatocellular and cholangiocarcinoma cell line (KMCH-2) that shows the features of hepatocellular carcinoma or cholangiocarcinoma under different growth conditions. J. Hepatol. 1996, 24, 413-422. [CrossRef]

47. Enjoji, M.; Sakai, H.; Nawata, H.; Kajiyama, K.; Tsuneyoshi, M. Sarcomatous and adenocarcinoma cell lines from the same nodule of cholangiocarcinoma. In Vitro Cell. Dev. Biol. Anim. 1997, 33, 681-683. [CrossRef]

48. Saha, S.K.; Parachoniak, C.A.; Ghanta, K.S.; Fitamant, J.; Ross, K.N.; Najem, M.S.; Gurumurthy, S.; Akbay, E.A.; Sia, D.; Cornella, H.; et al. Mutant IDH inhibits HNF- $4 \alpha$ to block hepatocyte differentiation and promote biliary cancer. Nature 2014, 513, 110-114. [CrossRef]

49. Steffen, M.; Zuehlke, I.; Scherdin, U. Motility factors identified in supernatants of human cholangiocarcinoma cell lines. Int. J. Oncol. 2001, 18, 1107-1112. [CrossRef]

50. Ku, J.L.; Yoon, K.A.; Kim, I.J.; Kim, W.H.; Jang, J.Y.; Suh, K.S.; Kim, S.W.; Park, Y.H.; Hwang, J.H.; Yoon, Y.B.; et al. Establishment and characterisation of six human biliary tract cancer cell lines. Br. J. Cancer 2002, 87, 187-193. [CrossRef]

51. Tepsiri, N.; Chaturat, L.; Sripa, B.; Namwat, W.; Wongkham, S.; Bhudhisawasdi, V.; Tassaneeyakul, W. Drug sensitivity and drug resistance profiles of human intrahepatic cholangiocarcinoma cell lines. World J. Gastroenterol. 2005, 11, 2748-2753. [CrossRef] [PubMed]

52. Ma, S.; Hu, L.; Huang, X.H.; Cao, L.Q.; Chan, K.W.; Wang, Q.; Guan, X.Y. Establishment and characterization of a human cholangiocarcinoma cell line. Oncol. Rep. 2007, 18, 1195-1200. [PubMed]

53. Ojima, H.; Yoshikawa, D.; Ino, Y.; Shimizu, H.; Miyamoto, M.; Kokubu, A.; Hiraoka, N.; Morofuji, N.; Kondo, T.; Onaya, H.; et al. Establishment of six new human biliary tract carcinoma cell lines and identification of MAGEH1 as a candidate biomarker for predicting the efficacy of gemcitabine treatment. Cancer Sci. 2010, 101, 882-888. [CrossRef] [PubMed] 
54. Obchoei, S.; Weakley, S.M.; Wongkham, S.; Wongkham, C.; Sawanyawisuth, K.; Yao, Q.; Chen, C. Cyclophilin A enhances cell proliferation and tumor growth of liver fluke-associated cholangiocarcinoma. Mol. Cancer 2011, 10, 102. [CrossRef] [PubMed]

55. Liu, J.; Han, G.; Liu, H.; Qin, C. Suppression of cholangiocarcinoma cell growth by human umbilical cord mesenchymal stem cells: A possible role of Wnt and Akt signaling. PLoS ONE 2013, 8, e62844. [CrossRef]

56. Cavalloni, G.; Peraldo-Neia, C.; Sassi, F.; Chiorino, G.; Sarotto, I.; Aglietta, M.; Leone, F. Establishment of a patient-derived intrahepatic cholangiocarcinoma xenograft model with KRAS mutation. BMC Cancer 2016, 16, 90. [CrossRef] [PubMed]

57. Varamo, C.; Peraldo-Neia, C.; Ostano, P.; Basiricò, M.; Raggi, C.; Bernabei, P.; Venesio, T.; Berrino, E.; Aglietta, M.; Leone, F.; et al. Establishment and Characterization of a New Intrahepatic Cholangiocarcinoma Cell Line Resistant to Gemcitabine. Cancers (Basel) 2019, 11, 519. [CrossRef]

58. Saensa-Ard, S.; Leuangwattanawanit, S.; Senggunprai, L.; Namwat, N.; Kongpetch, S.; Chamgramol, Y.; Loilome, W.; Khansaard, W.; Jusakul, A.; Prawan, A.; et al. Establishment of cholangiocarcinoma cell lines from patients in the endemic area of liver fluke infection in Thailand. Tumour Biol. 2017, 39. [CrossRef]

59. Zhang, Y.; Luo, J.; Dong, X.; Yang, F.; Zhang, M.; Zhao, J.; Wang, Q.; Zhou, F.; Sun, J.; Yang, X. Establishment and Characterization of Two Novel Cholangiocarcinoma Cell Lines. Ann. Surg. Oncol. 2019, 26, 4134-4147. [CrossRef]

60. Vaeteewoottacharn, K.; Pairojkul, C.; Kariya, R.; Muisuk, K.; Imtawil, K.; Chamgramol, Y.; Bhudhisawasdi, V.; Khuntikeo, N.; Pugkhem, A.; Saeseow, O.T.; et al. Establishment of Highly Transplantable Cholangiocarcinoma Cell Lines from a Patient-Derived Xenograft Mouse Model. Cells 2019, 8, 496. [CrossRef]

61. Sato, J.; Kimura, T.; Saito, T.; Anazawa, T.; Kenjo, A.; Sato, Y.; Tsuchiya, T.; Gotoh, M. Gene expression analysis for predicting gemcitabine resistance in human cholangiocarcinoma. J. Hepatobiliary Pancreat. Sci. 2011, 18, 700-711. [CrossRef] [PubMed]

62. Wattanawongdon, W.; Hahnvajanawong, C.; Namwat, N.; Kanchanawat, S.; Boonmars, T.; Jearanaikoon, P.; Leelayuwat, C.; Techasen, A.; Seubwai, W. Establishment and characterization of gemcitabine-resistant human cholangiocarcinoma cell lines with multidrug resistance and enhanced invasiveness. Int. J. Oncol. 2015, 47, 398-410. [CrossRef] [PubMed]

63. Jiao, W.; Yakushiji, H.; Kitajima, Y.; Ogawa, A.; Miyazaki, K. Establishment and characterization of human hilar bile duct carcinoma cell line and cell strain. J. Hepatobiliary Pancreat. Surg. 2000, 7, 417-425. [CrossRef] [PubMed]

64. Sripa, B.; Leungwattanawanit, S.; Nitta, T.; Wongkham, C.; Bhudhisawasdi, V.; Puapairoj, A.; Sripa, C.; Miwa, M. Establishment and characterization of an opisthorchiasis-associated cholangiocarcinoma cell line (KKU-100). World J. Gastroenterol. 2005, 11, 3392-3397. [CrossRef]

65. Ghosh, M.; Koike, N.; Tsunoda, S.; Hirano, T.; Kaul, S.; Kashiwagi, H.; Kawamoto, T.; Ohkohchi, N.; Saijo, K.; Ohno, T.; et al. Characterization and genetic analysis in the newly established human bile duct cancer cell lines. Int. J. Oncol. 2005, 26, 449-456. [CrossRef]

66. Zach, S.; Birgin, E. Primary Cholangiocellular Carcinoma Cell Lines. J. Stem Cell Res. Transplant. 2015, $2,1013$.

67. Knuth, A.; Gabbert, H.; Dippold, W.; Klein, O.; Sachsse, W.; Bitter-Suermann, D.; Prellwitz, W.; Meyer zum Büschenfelde, K.H. Biliary adenocarcinoma. Characterisation of three new human tumor cell lines. J. Hepatol. 1985, 1, 579-596. [CrossRef]

68. Yoshida, K.; Tomizawa, H.; Ota, T.; Nagashima, T.; Kikuchi, H.; Watanabe, H.; Hashizaki, K.; Yonaha, A. Establishment and characterization of human cholaginocarcinoma, MEC, producing carbohydrate antigen 19-9. Hum. Cell 1990, 3, 346-351.

69. Yano, H.; Maruiwa, M.; Iemura, A.; Mizoguchi, A.; Kojiro, M. Establishment and characterization of a new human extrahepatic bile duct carcinoma cell line (KMBC). Cancer 1992, 69, 1664-1673. [CrossRef]

70. Saijyo, S.; Kudo, T.; Suzuki, M.; Katayose, Y.; Shinoda, M.; Muto, T.; Fukuhara, K.; Suzuki, T.; Matsuno, S. Establishment of a new extrahepatic bile duct carcinoma cell line, TFK-1. Tohoku J. Exp. Med. 1995, 177, 61-71. [CrossRef]

71. Jia, L.Q.; Osada, M.; Ishioka, C.; Gamo, M.; Ikawa, S.; Suzuki, T.; Shimodaira, H.; Niitani, T.; Kudo, T.; Akiyama, M.; et al. Screening the p53 status of human cell lines using a yeast functional assay. Mol. Carcinog. 1997, 19, 243-253. [CrossRef] 
72. Kawamoto, M.; Umebayashi, M.; Tanaka, H.; Koya, N.; Nakagawa, S.; Kawabe, K.; Onishi, H.; Nakamura, M.; Morisaki, T. Combined Gemcitabine and Metronidazole Is a Promising Therapeutic Strategy for Cancer Stem-like Cholangiocarcinoma. Anticancer Res. 2018, 38, 2739-2748. [CrossRef]

73. Yamada, N.; Chung, Y.S.; Arimoto, Y.; Sawada, T.; Seki, S.; Sowa, M. Establishment of a new human extrahepatic bile duct carcinoma cell line (OCUCh-LM1) and experimental liver metastatic model. Br. J. Cancer 1995, 71, 543-548. [CrossRef]

74. Wang, S.; Han, B.; Chen, Y. Role of type IV collagenase in tumor cell invasion and effect of laminin on invasive potential in bile duct carcinoma. Zhonghua Yi Xue Za Zhi 1995, 75, 660-662, 708. [PubMed]

75. Takiyama, I.; Terashima, M.; Ikeda, K.; Kawamura, H.; Kashiwaba, M.; Tamura, G.; Suto, T.; Nakashima, F.; Sasaki, R.; Saito, K. Establishment and characterization of a new human extrahepatic bile duct carcinoma cell line (ICBD-1). Oncol. Rep. 1998, 5, 463-467. [CrossRef] [PubMed]

76. Watanabe, M.; Chigusa, M.; Takahashi, H.; Nakamura, J.; Tanaka, H.; Ohno, T. High level of CA19-9, CA50, and CEA-producible human cholangiocarcinoma cell line changes in the secretion ratios in vitro or in vivo. In Vitro Cell. Dev. Biol. Anim. 2000, 36, 104-109. [CrossRef]

77. Kim, D.G.; Park, S.Y.; You, K.R.; Lee, G.B.; Kim, H.; Moon, W.S.; Chun, Y.H.; Park, S.H. Establishment and characterization of chromosomal aberrations in human cholangiocarcinoma cell lines by cross-species color banding. Genes Chromosomes Cancer 2001, 30, 48-56. [CrossRef]

78. Yoon, H.; Min, J.K.; Lee, D.G.; Kim, D.G.; Koh, S.S.; Hong, H.J. L1 cell adhesion molecule and epidermal growth factor receptor activation confer cisplatin resistance in intrahepatic cholangiocarcinoma cells. Cancer Lett. 2012, 316, 70-76. [CrossRef]

79. Rattanasinganchan, P.; Leelawat, K.; Treepongkaruna, S.A.; Tocharoentanaphol, C.; Subwongcharoen, S.; Suthiphongchai, T.; Tohtong, R. Establishment and characterization of a cholangiocarcinoma cell line (RMCCA-1) from a Thai patient. World J. Gastroenterol. 2006, 12, 6500-6506. [CrossRef]

80. Murakami, T.; Yano, H.; Maruiwa, M.; Sugihara, S.; Kojiro, M. Establishment and characterization of a human combined hepatocholangiocarcinoma cell line and its heterologous transplantation in nude mice. Hepatology 1987, 7, 551-556. [CrossRef]

81. Hasan, S.; Taha, R.; Omri, H.E. Current Opinions on Chemoresistance: An Overview. Bioinformation 2018, 14, 80-85. [CrossRef] [PubMed]

82. Pan, J.B.; Hou, Y.H.; Zhang, G.J. Correlation between EGFR mutations and serum tumor markers in lung adenocarcinoma patients. Asian Pac. J. Cancer Prev. 2013, 14, 695-700. [CrossRef] [PubMed]

83. Mirone, G.; Shukla, A.; Marfe, G. Signaling mechanisms of resistance to EGFR- and Anti-Angiogenic Inhibitors cancer. Crit. Rev. Oncol. Hematol. 2016, 97, 85-95. [CrossRef] [PubMed]

84. Peng, R.; Chen, Y.; Wei, L.; Li, G.; Feng, D.; Liu, S.; Jiang, R.; Zheng, S. Resistance to FGFR1-targeted therapy leads to autophagy via TAK1/AMPK activation in gastric cancer. Gastric. Cancer 2020. [CrossRef] [PubMed]

85. Liu, B.; Saber, A.; Haisma, H.J. CRISPR/Cas9: A powerful tool for identification of new targets for cancer treatment. Drug Discov. Today 2019, 24, 955-970. [CrossRef]

86. Yoshino, J.; Akiyama, Y.; Shimada, S.; Ogura, T.; Ogawa, K.; Ono, H.; Mitsunori, Y.; Ban, D.; Kudo, A.; Yamaoka, S.; et al. Loss of ARID1A induces a stemness gene ALDH1A1 expression with histone acetylation in the malignant subtype of cholangiocarcinoma. Carcinogenesis 2020, 41, 734-742. [CrossRef]

87. Zhan, T.; Rindtorff, N.; Betge, J.; Ebert, M.P.; Boutros, M. CRISPR/Cas9 for cancer research and therapy. Semin. Cancer Biol. 2019, 55, 106-119. [CrossRef]

88. Martinez-Lage, M.; Puig-Serra, P.; Menendez, P.; Torres-Ruiz, R.; Rodriguez-Perales, S. CRISPR/Cas9 for Cancer Therapy: Hopes and Challenges. Biomedicines 2018, 6, 105. [CrossRef]

89. Kaur, G.; Dufour, J.M. Cell lines: Valuable tools or useless artifacts. Spermatogenesis 2012, 2, 1-5. [CrossRef]

90. Pastor, D.M.; Poritz, L.S.; Olson, T.L.; Kline, C.L.; Harris, L.R.; Koltun, W.A.; Chinchilli, V.M.; Irby, R.B. Primary cell lines: False representation or model system? a comparison of four human colorectal tumors and their coordinately established cell lines. Int. J. Clin. Exp. Med. 2010, 3, 69-83.

91. Chen, Z.; Guo, P.; Xie, X.; Yu, H.; Wang, Y.; Chen, G. The role of tumour microenvironment: A new vision for cholangiocarcinoma. J. Cell. Mol. Med. 2019, 23, 59-69. [CrossRef] [PubMed]

92. Cadamuro, M.; Morton, S.D.; Strazzabosco, M.; Fabris, L. Unveiling the role of tumor reactive stroma in cholangiocarcinoma: An opportunity for new therapeutic strategies. Transl. Gastrointest Cancer 2013, 2, 130-144. [CrossRef] [PubMed] 
93. Fabris, L.; Strazzabosco, M.; Crosby, H.A.; Ballardini, G.; Hubscher, S.G.; Kelly, D.A.; Neuberger, J.M.; Strain, A.J.; Joplin, R. Characterization and isolation of ductular cells coexpressing neural cell adhesion molecule and Bcl-2 from primary cholangiopathies and ductal plate malformations. Am. J. Pathol. 2000, 156, 1599-1612. [CrossRef]

94. Holt, A.P.; Haughton, E.L.; Lalor, P.F.; Filer, A.; Buckley, C.D.; Adams, D.H. Liver myofibroblasts regulate infiltration and positioning of lymphocytes in human liver. Gastroenterology 2009, 136, 705-714. [CrossRef]

95. Massani, M.; Stecca, T.; Fabris, L.; Caratozzolo, E.; Ruffolo, C.; Furlanetto, A.; Morton, S.; Cadamuro, M.; Strazzabosco, M.; Bassi, N. Isolation and characterization of biliary epithelial and stromal cells from resected human cholangiocarcinoma: A novel in vitro model to study tumor-stroma interactions. Oncol. Rep. 2013, 30, 1143-1148. [CrossRef]

96. Ohira, S.; Itatsu, K.; Sasaki, M.; Harada, K.; Sato, Y.; Zen, Y.; Ishikawa, A.; Oda, K.; Nagasaka, T.; Nimura, Y.; et al. Local balance of transforming growth factor-beta1 secreted from cholangiocarcinoma cells and stromal-derived factor-1 secreted from stromal fibroblasts is a factor involved in invasion of cholangiocarcinoma. Pathol. Int. 2006, 56, 381-389. [CrossRef]

97. Gentilini, A.; Rombouts, K.; Galastri, S.; Caligiuri, A.; Mingarelli, E.; Mello, T.; Marra, F.; Mantero, S.; Roncalli, M.; Invernizzi, P.; et al. Role of the stromal-derived factor-1 (SDF-1)-CXCR4 axis in the interaction between hepatic stellate cells and cholangiocarcinoma. J. Hepatol. 2012, 57, 813-820. [CrossRef]

98. Chuaysri, C.; Thuwajit, P.; Paupairoj, A.; Chau-In, S.; Suthiphongchai, T.; Thuwajit, C. Alpha-smooth muscle actin-positive fibroblasts promote biliary cell proliferation and correlate with poor survival in cholangiocarcinoma. Oncol. Rep. 2009, 21, 957-969. [CrossRef]

99. Dutta, S.; Reamtong, O.; Panvongsa, W.; Kitdumrongthum, S.; Janpipatkul, K.; Sangvanich, P.; Piyachaturawat, P.; Chairoungdua, A. Proteomics profiling of cholangiocarcinoma exosomes: A potential role of oncogenic protein transferring in cancer progression. Biochim. Biophys. Acta 2015, 1852, 1989-1999. [CrossRef]

100. Yang, X.; Li, Y.; Zou, L.; Zhu, Z. Role of Exosomes in Crosstalk Between Cancer-Associated Fibroblasts and Cancer Cells. Front. Oncol. 2019, 9, 356. [CrossRef]

101. Li, L.; Piontek, K.; Ishida, M.; Fausther, M.; Dranoff, J.A.; Fu, R.; Mezey, E.; Gould, S.J.; Fordjour, F.K.; Meltzer, S.J.; et al. Extracellular vesicles carry microRNA-195 to intrahepatic cholangiocarcinoma and improve survival in a rat model. Hepatology 2017, 65, 501-514. [CrossRef] [PubMed]

102. Chen, J.H.; Xiang, J.Y.; Ding, G.P.; Cao, L.P. Cholangiocarcinoma-derived exosomes inhibit the antitumor activity of cytokine-induced killer cells by down-regulating the secretion of tumor necrosis factor- $\alpha$ and perforin. J Zhejiang Univ. Sci. B 2016, 17, 537-544. [CrossRef] [PubMed]

103. Stock, K.; Estrada, M.F.; Vidic, S.; Gjerde, K.; Rudisch, A.; Santo, V.E.; Barbier, M.; Blom, S.; Arundkar, S.C.; Selvam, I.; et al. Capturing tumor complexity in vitro: Comparative analysis of 2D and 3D tumor models for drug discovery. Sci. Rep. 2016, 6, 28951. [CrossRef] [PubMed]

104. Baker, B.M.; Chen, C.S. Deconstructing the third dimension: How 3D culture microenvironments alter cellular cues. J. Cell Sci. 2012, 125, 3015-3024. [CrossRef] [PubMed]

105. Fitzgerald, K.A.; Malhotra, M.; Curtin, C.M.; O' Brien, F.J.; O' Driscoll, C.M. Life in 3D is never flat: 3D models to optimise drug delivery. J. Control. Release 2015, 215, 39-54. [CrossRef] [PubMed]

106. Kinney, M.A.; Hookway, T.A.; Wang, Y.; McDevitt, T.C. Engineering three-dimensional stem cell morphogenesis for the development of tissue models and scalable regenerative therapeutics. Ann. Biomed. Eng. 2014, 42, 352-367. [CrossRef]

107. Song, K.; Wang, Z.; Liu, R.; Chen, G.; Liu, L. Microfabrication-Based Three-Dimensional (3-D) Extracellular Matrix Microenvironments for Cancer and Other Diseases. Int. J. Mol. Sci. 2018, 19, 935. [CrossRef]

108. Fan, Q.; Liu, R.; Jiao, Y.; Tian, C.; Farrell, J.D.; Diao, W.; Wang, X.; Zhang, F.; Yuan, W.; Han, H.; et al. A novel 3-D bio-microfluidic system mimicking in vivo heterogeneous tumour microstructures reveals complex tumour-stroma interactions. Lab Chip 2017, 17, 2852-2860. [CrossRef]

109. Mao, S.; He, J.; Zhao, Y.; Liu, T.; Xie, F.; Yang, H.; Mao, Y.; Pang, Y.; Sun, W. Bioprinting of patient-derived. Biofabrication 2020. [CrossRef]

110. Discher, D.E.; Janmey, P.; Wang, Y.L. Tissue cells feel and respond to the stiffness of their substrate. Science 2005, 310, 1139-1143. [CrossRef]

111. Duval, K.; Grover, H.; Han, L.H.; Mou, Y.; Pegoraro, A.F.; Fredberg, J.; Chen, Z. Modeling Physiological Events in 2D vs. 3D Cell Culture. Physiology (Bethesda) 2017, 32, 266-277. [CrossRef] [PubMed] 
112. Wang, K.; Cai, L.H.; Lan, B.; Fredberg, J.J. Hidden in the mist no more: Physical force in cell biology. Nat. Methods 2016, 13, 124-125. [CrossRef] [PubMed]

113. Sutherland, R.M.; McCredie, J.A.; Inch, W.R. Growth of multicell spheroids in tissue culture as a model of nodular carcinomas. J. Natl. Cancer Inst. 1971, 46, 113-120. [PubMed]

114. Zanoni, M.; Cortesi, M.; Zamagni, A.; Arienti, C.; Pignatta, S.; Tesei, A. Modeling neoplastic disease with spheroids and organoids. J. Hematol. Oncol. 2020, 13, 97. [CrossRef] [PubMed]

115. Ishiguro, T.; Ohata, H.; Sato, A.; Yamawaki, K.; Enomoto, T.; Okamoto, K. Tumor-derived spheroids: Relevance to cancer stem cells and clinical applications. Cancer Sci. 2017, 108, 283-289. [CrossRef]

116. Ayob, A.Z.; Ramasamy, T.S. Cancer stem cells as key drivers of tumour progression. J. Biomed. Sci. 2018, 25, 20. [CrossRef]

117. Keysar, S.B.; Jimeno, A. More than markers: Biological significance of cancer stem cell-defining molecules. Mol. Cancer Ther. 2010, 9, 2450-2457. [CrossRef]

118. Zhao, J. Cancer stem cells and chemoresistance: The smartest survives the raid. Pharmacol. Ther. 2016, 160, 145-158. [CrossRef]

119. Phi, L.T.H.; Sari, I.N.; Yang, Y.G.; Lee, S.H.; Jun, N.; Kim, K.S.; Lee, Y.K.; Kwon, H.Y. Cancer Stem Cells (CSCs) in Drug Resistance and their Therapeutic Implications in Cancer Treatment. Stem Cells Int. 2018, 2018, 5416923. [CrossRef]

120. Cardinale, V.; Renzi, A.; Carpino, G.; Torrice, A.; Bragazzi, M.C.; Giuliante, F.; DeRose, A.M.; Fraveto, A.; Onori, P.; Napoletano, C.; et al. Profiles of cancer stem cell subpopulations in cholangiocarcinomas. Am. J. Pathol. 2015, 185, 1724-1739. [CrossRef]

121. Mischiati, C.; Ura, B.; Roncoroni, L.; Elli, L.; Cervellati, C.; Squerzanti, M.; Conte, D.; Doneda, L.; Polverino de Laureto, P.; de Franceschi, G.; et al. Changes in protein expression in two cholangiocarcinoma cell lines undergoing formation of multicellular tumor spheroids in vitro. PLoS ONE 2015, 10, e0118906. [CrossRef] [PubMed]

122. Raggi, C.; Correnti, M.; Sica, A.; Andersen, J.B.; Cardinale, V.; Alvaro, D.; Chiorino, G.; Forti, E.; Glaser, S.; Alpini, G.; et al. Cholangiocarcinoma stem-like subset shapes tumor-initiating niche by educating associated macrophages. J. Hepatol. 2017, 66, 102-115. [CrossRef] [PubMed]

123. Wu, H.J.; Chu, P.Y. Role of Cancer Stem Cells in Cholangiocarcinoma and Therapeutic Implications. Int. J. Mol. Sci. 2019, 20, 4154. [CrossRef] [PubMed]

124. Marin, J.J.G.; Herraez, E.; Lozano, E.; Macias, R.I.R.; Briz, O. Models for Understanding Resistance to Chemotherapy in Liver Cancer. Cancers (Basel) 2019, 11, 1677. [CrossRef]

125. Cardinale, V.; Carpino, G.; Reid, L.; Gaudio, E.; Alvaro, D. Multiple cells of origin in cholangiocarcinoma underlie biological, epidemiological and clinical heterogeneity. World J. Gastrointest Oncol. 2012, 4, 94-102. [CrossRef]

126. Campbell, D.J.; Dumur, C.I.; Lamour, N.F.; Dewitt, J.L.; Sirica, A.E. Novel organotypic culture model of cholangiocarcinoma progression. Hepatol. Res. 2012, 42, 1119-1130. [CrossRef]

127. Rossi, G.; Manfrin, A.; Lutolf, M.P. Progress and potential in organoid research. Nat. Rev. Genet. 2018, 19, 671-687. [CrossRef]

128. Frantz, C.; Stewart, K.M.; Weaver, V.M. The extracellular matrix at a glance. J. Cell Sci. 2010, 123, 4195-4200. [CrossRef]

129. Kim, S.H.; Turnbull, J.; Guimond, S. Extracellular matrix and cell signalling: The dynamic cooperation of integrin, proteoglycan and growth factor receptor. J. Endocrinol. 2011, 209, 139-151. [CrossRef]

130. Sorrentino, G.; Rezakhani, S.; Yildiz, E.; Nuciforo, S.; Heim, M.H.; Lutolf, M.P.; Schoonjans, K. Mechano-modulatory synthetic niches for liver organoid derivation. Nat. Commun. 2020, 11, 3416. [CrossRef]

131. Grebenyuk, S.; Ranga, A. Engineering Organoid Vascularization. Front. Bioeng. Biotechnol. 2019, 7, 39. [CrossRef] [PubMed]

132. Vlachogiannis, G.; Hedayat, S.; Vatsiou, A.; Jamin, Y.; Fernández-Mateos, J.; Khan, K.; Lampis, A.; Eason, K.; Huntingford, I.; Burke, R.; et al. Patient-derived organoids model treatment response of metastatic gastrointestinal cancers. Science 2018, 359, 920-926. [CrossRef] [PubMed]

133. Driehuis, E.; van Hoeck, A.; Moore, K.; Kolders, S.; Francies, H.E.; Gulersonmez, M.C.; Stigter, E.C.A.; Burgering, B.; Geurts, V.; Gracanin, A.; et al. Pancreatic cancer organoids recapitulate disease and allow personalized drug screening. Proc. Natl. Acad. Sci. USA 2019. [CrossRef] [PubMed] 
134. Kim, M.; Mun, H.; Sung, C.O.; Cho, E.J.; Jeon, H.J.; Chun, S.M.; Jung, D.J.; Shin, T.H.; Jeong, G.S.; Kim, D.K.; et al. Patient-derived lung cancer organoids as in vitro cancer models for therapeutic screening. Nat. Commun. 2019, 10, 3991. [CrossRef] [PubMed]

135. Broutier, L.; Mastrogiovanni, G.; Verstegen, M.M.; Francies, H.E.; Gavarró, L.M.; Bradshaw, C.R.; Allen, G.E.; Arnes-Benito, R.; Sidorova, O.; Gaspersz, M.P.; et al. Human primary liver cancer-derived organoid cultures for disease modeling and drug screening. Nat. Med. 2017, 23, 1424-1435. [CrossRef]

136. Saito, Y.; Nakaoka, T.; Muramatsu, T.; Ojima, H.; Sukeda, A.; Sugiyama, Y.; Uchida, R.; Furukawa, R.; Kitahara, A.; Sato, T.; et al. Induction of differentiation of intrahepatic cholangiocarcinoma cells to functional hepatocytes using an organoid culture system. Sci. Rep. 2018, 8, 2821. [CrossRef]

137. Lampis, A.; Carotenuto, P.; Vlachogiannis, G.; Cascione, L.; Hedayat, S.; Burke, R.; Clarke, P.; Bosma, E.; Simbolo, M.; Scarpa, A.; et al. MIR21 Drives Resistance to Heat Shock Protein 90 Inhibition in Cholangiocarcinoma. Gastroenterology 2018, 154, 1066-1079.e1065. [CrossRef]

138. Saito, Y. Establishment of an organoid bank of biliary tract and pancreatic cancers and its application for personalized therapy and future treatment. J. Gastroenterol. Hepatol. 2019, 34, 1906-1910. [CrossRef]

139. Li, M.; Wang, L.; Wang, Y.; Zhang, S.; Zhou, G.; Lieshout, R.; Ma, B.; Liu, J.; Qu, C.; Verstegen, M.M.A.; et al. Mitochondrial Fusion Via OPA1 and MFN1 Supports Liver Tumor Cell Metabolism and Growth. Cells 2020, 9, 121. [CrossRef]

140. Koedijk, M.S.; Heijmen, B.J.M.; Groot Koerkamp, B.; Eskens, F.A.L.M.; Sprengers, D.; Poley, J.W.; van Gent, D.C.; van der Laan, L.J.W.; van der Holt, B.; Willemssen, F.E.J.A.; et al. Protocol for the STRONG trial: Stereotactic body radiation therapy following chemotherapy for unresectable perihilar cholangiocarcinoma, a phase I feasibility study. BMJ Open 2018, 8, e020731. [CrossRef]

141. Artegiani, B.; van Voorthuijsen, L.; Lindeboom, R.G.H.; Seinstra, D.; Heo, I.; Tapia, P.; López-Iglesias, C.; Postrach, D.; Dayton, T.; Oka, R.; et al. Probing the Tumor Suppressor Function of BAP1 in CRISPR-Engineered Human Liver Organoids. Cell Stem Cell 2019, 24, 927-943.e926. [CrossRef] [PubMed]

142. Sun, L.; Wang, Y.; Cen, J.; Ma, X.; Cui, L.; Qiu, Z.; Zhang, Z.; Li, H.; Yang, R.Z.; Wang, C.; et al. Modelling liver cancer initiation with organoids derived from directly reprogrammed human hepatocytes. Nat. Cell Biol. 2019, 21, 1015-1026. [CrossRef] [PubMed]

143. Li, L.; Qian, M.; Chen, I.H.; Finkelstein, D.; Onar-Thomas, A.; Johnson, M.; Calabrese, C.; Bahrami, A.; López-Terrada, D.H.; Yang, J.J.; et al. Acquisition of Cholangiocarcinoma Traits during Advanced Hepatocellular Carcinoma Development in Mice. Am. J. Pathol. 2018, 188, 656-671. [CrossRef]

144. Nuciforo, S.; Fofana, I.; Matter, M.S.; Blumer, T.; Calabrese, D.; Boldanova, T.; Piscuoglio, S.; Wieland, S.; Ringnalda, F.; Schwank, G.; et al. Organoid Models of Human Liver Cancers Derived from Tumor Needle Biopsies. Cell Rep. 2018, 24, 1363-1376. [CrossRef] [PubMed]

145. Romero-Calvo, I.; Weber, C.R.; Ray, M.; Brown, M.; Kirby, K.; Nandi, R.K.; Long, T.M.; Sparrow, S.M.; Ugolkov, A.; Qiang, W.; et al. Human Organoids Share Structural and Genetic Features with Primary Pancreatic Adenocarcinoma Tumors. Mol. Cancer Res. 2019, 17, 70-83. [CrossRef]

146. Loeuillard, E.; Fischbach, S.R.; Gores, G.J.; Rizvi, S. Animal models of cholangiocarcinoma. Biochim. Biophys. Acta Mol. Basis Dis. 2019, 1865, 982-992. [CrossRef]

147. Thamavit, W.; Bhamarapravati, N.; Sahaphong, S.; Vajrasthira, S.; Angsubhakorn, S. Effects of dimethylnitrosamine on induction of cholangiocarcinoma in Opisthorchis viverrini-infected Syrian golden hamsters. Cancer Res. 1978, 38, 4634-4639.

148. Tolba, R.; Kraus, T.; Liedtke, C.; Schwarz, M.; Weiskirchen, R. Diethylnitrosamine (DEN)-induced carcinogenic liver injury in mice. Lab. Anim. 2015, 49, 59-69. [CrossRef]

149. Umemura, T.; Kai, S.; Hasegawa, R.; Kanki, K.; Kitamura, Y.; Nishikawa, A.; Hirose, M. Prevention of dual promoting effects of pentachlorophenol, an environmental pollutant, on diethylnitrosamine-induced hepatoand cholangiocarcinogenesis in mice by green tea infusion. Carcinogenesis 2003, 24, 1105-1109. [CrossRef]

150. Yang, H.; Li, T.W.; Peng, J.; Tang, X.; Ko, K.S.; Xia, M.; Aller, M.A. A mouse model of cholestasis-associated cholangiocarcinoma and transcription factors involved in progression. Gastroenterology 2011, 141, 378-388.e4. [CrossRef]

151. Yang, C.S.; Smith, T.; Ishizaki, H.; Hong, J.Y. Enzyme mechanisms in the metabolism of nitrosamines. IARC Sci. Publ. 1991, 105, 265-274.

152. Maronpot, R.R.; Giles, H.D.; Dykes, D.J.; Irwin, R.D. Furan-induced hepatic cholangiocarcinomas in Fischer 344 rats. Toxicol. Pathol. 1991, 19, 561-570. [CrossRef] [PubMed] 
153. Elmore, L.W.; Sirica, A.E. Phenotypic characterization of metaplastic intestinal glands and ductular hepatocytes in cholangiofibrotic lesions rapidly induced in the caudate liver lobe of rats treated with furan. Cancer Res. 1991, 51, 5752-5759. [PubMed]

154. Yeh, C.N.; Maitra, A.; Lee, K.F.; Jan, Y.Y.; Chen, M.F. Thioacetamide-induced intestinal-type cholangiocarcinoma in rat: An animal model recapitulating the multi-stage progression of human cholangiocarcinoma. Carcinogenesis 2004, 25, 631-636. [CrossRef] [PubMed]

155. Marzioni, M.; Torrice, A.; Saccomanno, S.; Rychlicki, C.; Agostinelli, L.; Pierantonelli, I.; Rhönnstad, P.; Trozzi, L.; Apelqvist, T.; Gentile, R.; et al. An oestrogen receptor $\beta$-selective agonist exerts anti-neoplastic effects in experimental intrahepatic cholangiocarcinoma. Dig. Liver Dis. 2012, 44, 134-142. [CrossRef] [PubMed]

156. Pritchard, J.B.; French, J.E.; Davis, B.J.; Haseman, J.K. The role of transgenic mouse models in carcinogen identification. Environ. Health Perspect. 2003, 111, 444-454. [CrossRef] [PubMed]

157. Kumar, T.R.; Larson, M.; Wang, H.; McDermott, J.; Bronshteyn, I. Transgenic mouse technology: Principles and methods. Methods Mol. Biol. 2009, 590, 335-362. [CrossRef]

158. Kang, Y.K.; Kim, W.H.; Jang, J.J. Expression of G1-S modulators (p53, p16, p27, cyclin D1, Rb) and Smad4/Dpc4 in intrahepatic cholangiocarcinoma. Hum. Pathol. 2002, 33, 877-883. [CrossRef]

159. Downward, J. Mechanisms and consequences of activation of protein kinase B/Akt. Curr. Opin. Cell Biol. 1998, 10, 262-267. [CrossRef]

160. Xu, X.; Kobayashi, S.; Qiao, W.; Li, C.; Xiao, C.; Radaeva, S.; Stiles, B.; Wang, R.H.; Ohara, N.; Yoshino, T.; et al. Induction of intrahepatic cholangiocellular carcinoma by liver-specific disruption of Smad 4 and Pten in mice. J. Clin. Investig. 2006, 116, 1843-1852. [CrossRef]

161. Ikenoue, T.; Terakado, Y.; Nakagawa, H.; Hikiba, Y.; Fujii, T.; Matsubara, D.; Noguchi, R.; Zhu, C.; Yamamoto, K.; Kudo, Y.; et al. A novel mouse model of intrahepatic cholangiocarcinoma induced by liver-specific Kras activation and Pten deletion. Sci. Rep. 2016, 6, 23899. [CrossRef] [PubMed]

162. O'Dell, M.R.; Huang, J.L.; Whitney-Miller, C.L.; Deshpande, V.; Rothberg, P.; Grose, V.; Rossi, R.M.; Zhu, A.X.; Land, H.; Bardeesy, N.; et al. Kras(G12D) and p53 mutation cause primary intrahepatic cholangiocarcinoma. Cancer Res. 2012, 72, 1557-1567. [CrossRef] [PubMed]

163. Wang, P.; Dong, Q.; Zhang, C.; Kuan, P.F.; Liu, Y.; Jeck, W.R.; Andersen, J.B.; Jiang, W.; Savich, G.L.; Tan, T.X.; et al. Mutations in isocitrate dehydrogenase 1 and 2 occur frequently in intrahepatic cholangiocarcinomas and share hypermethylation targets with glioblastomas. Oncogene 2013, 32, 3091-3100. [CrossRef] [PubMed]

164. Kiguchi, K.; Carbajal, S.; Chan, K.; Beltrán, L.; Ruffino, L.; Shen, J.; Matsumoto, T.; Yoshimi, N.; DiGiovanni, J. Constitutive expression of ErbB-2 in gallbladder epithelium results in development of adenocarcinoma. Cancer Res. 2001, 61, 6971-6976.

165. Yu, D.; Hung, M.C. Overexpression of ErbB2 in cancer and ErbB2-targeting strategies. Oncogene 2000, 19, 6115-6121. [CrossRef]

166. Zender, S.; Nickeleit, I.; Wuestefeld, T.; Sörensen, I.; Dauch, D.; Bozko, P.; El-Khatib, M.; Geffers, R.; Bektas, H.; Manns, M.P.; et al. A critical role for notch signaling in the formation of cholangiocellular carcinomas. Cancer Cell 2013, 23, 784-795. [CrossRef]

167. Hofmann, J.J.; Zovein, A.C.; Koh, H.; Radtke, F.; Weinmaster, G.; Iruela-Arispe, M.L. Jagged1 in the portal vein mesenchyme regulates intrahepatic bile duct development: Insights into Alagille syndrome. Development 2010, 137, 4061-4072. [CrossRef]

168. Farazi, P.A.; Zeisberg, M.; Glickman, J.; Zhang, Y.; Kalluri, R.; DePinho, R.A. Chronic bile duct injury associated with fibrotic matrix microenvironment provokes cholangiocarcinoma in p53-deficient mice. Cancer Res. 2006, 66, 6622-6627. [CrossRef]

169. Cadamuro, M.; Stecca, T.; Brivio, S.; Mariotti, V.; Fiorotto, R.; Spirli, C.; Strazzabosco, M.; Fabris, L. The deleterious interplay between tumor epithelia and stroma in cholangiocarcinoma. Biochim. Biophys. Acta Mol. Basis Dis. 2018, 1864, 1435-1443. [CrossRef]

170. He, L.; Tian, D.A.; Li, P.Y.; He, X.X. Mouse models of liver cancer: Progress and recommendations. Oncotarget 2015, 6, 23306-23322. [CrossRef]

171. Suda, T.; Liu, D. Hydrodynamic gene delivery: Its principles and applications. Mol. Ther. 2007, 15, $2063-2069$. [CrossRef] [PubMed] 
172. Crespo, A.; Peydró, A.; Dasí, F.; Benet, M.; Calvete, J.J.; Revert, F.; Aliño, S.F. Hydrodynamic liver gene transfer mechanism involves transient sinusoidal blood stasis and massive hepatocyte endocytic vesicles. Gene Ther. 2005, 12, 927-935. [CrossRef] [PubMed]

173. Zhang, S.; Wang, J.; Wang, H.; Fan, L.; Fan, B.; Zeng, B.; Tao, J.; Li, X.; Che, L.; Cigliano, A.; et al. Hippo Cascade Controls Lineage Commitment of Liver Tumors in Mice and Humans. Am. J. Pathol. 2018, 188, 995-1006. [CrossRef] [PubMed]

174. Liu, F.; Song, Y.; Liu, D. Hydrodynamics-based transfection in animals by systemic administration of plasmid DNA. Gene Ther. 1999, 6, 1258-1266. [CrossRef] [PubMed]

175. Dagnaes-Hansen, F.; Holst, H.U.; Søndergaard, M.; Vorup-Jensen, T.; Flyvbjerg, A.; Jensen, U.B.; Jensen, T.G. Physiological effects of human growth hormone produced after hydrodynamic gene transfer of a plasmid vector containing the human ubiquitin promotor. J. Mol. Med. (Berl.) 2002, 80, 665-670. [CrossRef]

176. Vorup-Jensen, T.; Jensen, U.B.; Liu, H.; Kawasaki, T.; Uemura, K.; Thiel, S.; Dagnaes-Hansen, F.; Jensen, T.G. Tail-vein injection of mannan-binding lectin DNA leads to high expression levels of multimeric protein in liver. Mol. Ther. 2001, 3, 867-874. [CrossRef]

177. Giladi, H.; Ketzinel-Gilad, M.; Rivkin, L.; Felig, Y.; Nussbaum, O.; Galun, E. Small interfering RNA inhibits hepatitis B virus replication in mice. Mol. Ther. 2003, 8, 769-776. [CrossRef]

178. Maruyama, H.; Higuchi, N.; Nishikawa, Y.; Kameda, S.; Iino, N.; Kazama, J.J.; Takahashi, N.; Sugawa, M.; Hanawa, H.; Tada, N.; et al. High-level expression of naked DNA delivered to rat liver via tail vein injection. J. Gene Med. 2002, 4, 333-341. [CrossRef]

179. Zhang, G.; Gao, X.; Song, Y.K.; Vollmer, R.; Stolz, D.B.; Gasiorowski, J.Z.; Dean, D.A.; Liu, D. Hydroporation as the mechanism of hydrodynamic delivery. Gene Ther. 2004, 11, 675-682. [CrossRef]

180. Xue, W.; Chen, S.; Yin, H.; Tammela, T.; Papagiannakopoulos, T.; Joshi, N.S.; Cai, W.; Yang, G.; Bronson, R.; Crowley, D.G.; et al. CRISPR-mediated direct mutation of cancer genes in the mouse liver. Nature 2014, 514, 380-384. [CrossRef]

181. Carlson, C.M.; Frandsen, J.L.; Kirchhof, N.; McIvor, R.S.; Largaespada, D.A. Somatic integration of an oncogene-harboring Sleeping Beauty transposon models liver tumor development in the mouse. Proc. Natl. Acad. Sci. USA 2005, 102, 17059-17064. [CrossRef] [PubMed]

182. Ozenne, P.; Eymin, B.; Brambilla, E.; Gazzeri, S. The ARF tumor suppressor: Structure, functions and status in cancer. Int. J. Cancer 2010, 127, 2239-2247. [CrossRef] [PubMed]

183. Zhang, S.; Song, X.; Cao, D.; Xu, Z.; Fan, B.; Che, L.; Hu, J.; Chen, B.; Dong, M.; Pilo, M.G.; et al. Pan-mTOR inhibitor MLN0128 is effective against intrahepatic cholangiocarcinoma in mice. J. Hepatol. 2017, 67, 1194-1203. [CrossRef]

184. Wang, J.; Dong, M.; Xu, Z.; Song, X.; Zhang, S.; Qiao, Y.; Che, L.; Gordan, J.; Hu, K.; Liu, Y.; et al. Notch2 controls hepatocyte-derived cholangiocarcinoma formation in mice. Oncogene 2018, 37, 3229-3242. [CrossRef] [PubMed]

185. Richmond, A.; Su, Y. Mouse xenograft models vs GEM models for human cancer therapeutics. Dis. Model Mech. 2008, 1, 78-82. [CrossRef] [PubMed]

186. Day, C.P.; Merlino, G.; Van Dyke, T. Preclinical mouse cancer models: A maze of opportunities and challenges. Cell 2015, 163, 39-53. [CrossRef] [PubMed]

187. Hudd, C.; Euhus, D.M.; LaRegina, M.C.; Herbold, D.R.; Palmer, D.C.; Johnson, F.E. Effect of cholecystokinin on human cholangiocarcinoma xenografted into nude mice. Cancer Res. 1985, 45, 1372-1377.

188. De Minicis, S.; Kisseleva, T.; Francis, H.; Baroni, G.S.; Benedetti, A.; Brenner, D.; Alvaro, D.; Alpini, G.; Marzioni, M. Liver carcinogenesis: Rodent models of hepatocarcinoma and cholangiocarcinoma. Dig. Liver Dis. 2013, 45, 450-459. [CrossRef]

189. Cavalloni, G.; Peraldo-Neia, C.; Sarotto, I.; Gammaitoni, L.; Migliardi, G.; Soster, M.; Marchiò, S.; Aglietta, M.; Leone, F. Antitumor activity of Src inhibitor saracatinib (AZD-0530) in preclinical models of biliary tract carcinomas. Mol. Cancer Ther. 2012, 11, 1528-1538. [CrossRef]

190. Samukawa, E.; Fujihara, S.; Oura, K.; Iwama, H.; Yamana, Y.; Tadokoro, T.; Chiyo, T.; Kobayashi, K.; Morishita, A.; Nakahara, M.; et al. Angiotensin receptor blocker telmisartan inhibits cell proliferation and tumor growth of cholangiocarcinoma through cell cycle arrest. Int. J. Oncol. 2017, 51, 1674-1684. [CrossRef]

191. Tang, T.; Zheng, J.W.; Chen, B.; Li, H.; Li, X.; Xue, K.Y.; Ai, X.; Zou, S.Q. Effects of targeting magnetic drug nanoparticles on human cholangiocarcinoma xenografts in nude mice. Hepatobiliary Pancreat. Dis. Int. 2007, $6,303-307$. 
192. Zhao, X.; Zhang, C.; Zhou, H.; Xiao, B.; Cheng, Y.; Wang, J.; Yao, F.; Duan, C.; Chen, R.; Liu, Y.; et al. Synergistic antitumor activity of the combination of salubrinal and rapamycin against human cholangiocarcinoma cells. Oncotarget 2016, 7, 85492-85501. [CrossRef]

193. Fava, G.; Marucci, L.; Glaser, S.; Francis, H.; De Morrow, S.; Benedetti, A.; Alvaro, D.; Venter, J.; Meininger, C.; Patel, T.; et al. gamma-Aminobutyric acid inhibits cholangiocarcinoma growth by cyclic AMP-dependent regulation of the protein kinase A/extracellular signal-regulated kinase 1/2 pathway. Cancer Res. 2005, 65, 11437-11446. [CrossRef]

194. Frampton, G.A.; Lazcano, E.A.; Li, H.; Mohamad, A.; DeMorrow, S. Resveratrol enhances the sensitivity of cholangiocarcinoma to chemotherapeutic agents. Lab. Investig. 2010, 90, 1325-1338. [CrossRef] [PubMed]

195. Jo, H.J.; Shim, H.E.; Han, M.E.; Kim, H.J.; Kim, K.S.; Baek, S.; Choi, K.U.; Hur, G.Y.; Oh, S.O. WTAP regulates migration and invasion of cholangiocarcinoma cells. J. Gastroenterol. 2013, 48, 1271-1282. [CrossRef] [PubMed]

196. Lang, M.; Henson, R.; Braconi, C.; Patel, T. Epigallocatechin-gallate modulates chemotherapy-induced apoptosis in human cholangiocarcinoma cells. Liver Int. 2009, 29, 670-677. [CrossRef] [PubMed]

197. Meng, F.; Yamagiwa, Y.; Ueno, Y.; Patel, T. Over-expression of interleukin-6 enhances cell survival and transformed cell growth in human malignant cholangiocytes. J. Hepatol. 2006, 44, 1055-1065. [CrossRef]

198. Merino-Azpitarte, M.; Lozano, E.; Perugorria, M.J.; Esparza-Baquer, A.; Erice, O.; Santos-Laso, Á.; O'Rourke, C.J.; Andersen, J.B.; Jiménez-Agüero, R.; Lacasta, A.; et al. SOX17 regulates cholangiocyte differentiation and acts as a tumor suppressor in cholangiocarcinoma. J. Hepatol. 2017, 67, 72-83. [CrossRef]

199. Yang, R.; Chen, Y.; Tang, C.; Li, H.; Wang, B.; Yan, Q.; Hu, J.; Zou, S. MicroRNA-144 suppresses cholangiocarcinoma cell proliferation and invasion through targeting platelet activating factor acetylhydrolase isoform 1b. BMC Cancer 2014, 14, 917. [CrossRef]

200. Ursu, S.; Majid, S.; Garger, C.; de Semir, D.; Bezrookove, V.; Desprez, P.Y.; McAllister, S.; Soroceanu, L.; Nosrati, M.; Yimam, K.; et al. Novel tumor suppressor role of miRNA-876 in cholangiocarcinoma. Oncogenesis 2019, 8, 42. [CrossRef]

201. Cadamuro, M.; Brivio, S.; Stecca, T.; Kaffe, E.; Mariotti, V.; Milani, C.; Fiorotto, R.; Spirli, C.; Strazzabosco, M.; Fabris, L. Animal models of cholangiocarcinoma: What they teach us about the human disease. Clin. Res. Hepatol. Gastroenterol. 2018, 42, 403-415. [CrossRef] [PubMed]

202. Li, E.; Lin, L.; Chen, C.W.; Ou, D.L. Mouse Models for Immunotherapy in Hepatocellular Carcinoma. Cancers (Basel) 2019, 11, 1800. [CrossRef] [PubMed]

203. Sanmamed, M.F.; Chester, C.; Melero, I.; Kohrt, H. Defining the optimal murine models to investigate immune checkpoint blockers and their combination with other immunotherapies. Ann. Oncol. 2016, 27, 1190-1198. [CrossRef] [PubMed]

204. Rizvi, S.; Fischbach, S.R.; Bronk, S.F.; Hirsova, P.; Krishnan, A.; Dhanasekaran, R.; Smadbeck, J.B.; Smoot, R.L.; Vasmatzis, G.; Gores, G.J. YAP-associated chromosomal instability and cholangiocarcinoma in mice. Oncotarget 2018, 9, 5892-5905. [CrossRef] [PubMed]

205. Wu, Z.; Boonmars, T.; Nagano, I.; Boonjaraspinyo, S.; Srinontong, P.; Ratasuwan, P.; Narong, K.; Nielsen, P.S.; Maekawa, Y. Significance of S100P as a biomarker in diagnosis, prognosis and therapy of opisthorchiasis-associated cholangiocarcinoma. Int. J. Cancer 2016, 138, 396-408. [CrossRef] [PubMed]

206. Cadamuro, M.; Spagnuolo, G.; Sambado, L.; Indraccolo, S.; Nardo, G.; Rosato, A.; Brivio, S.; Caslini, C.; Stecca, T.; Massani, M.; et al. Low-Dose Paclitaxel Reduces S100A4 Nuclear Import to Inhibit Invasion and Hematogenous Metastasis of Cholangiocarcinoma. Cancer Res. 2016, 76, 4775-4784. [CrossRef]

207. Erice, O.; Labiano, I.; Arbelaiz, A.; Santos-Laso, A.; Munoz-Garrido, P.; Jimenez-Agüero, R.; Olaizola, P.; Caro-Maldonado, A.; Martín-Martín, N.; Carracedo, A.; et al. Differential effects of FXR or TGR5 activation in cholangiocarcinoma progression. Biochim. Biophys. Acta Mol. Basis Dis. 2018, 1864, 1335-1344. [CrossRef]

208. McVeigh, L.E.; Wijetunga, I.; Ingram, N.; Marston, G.; Prasad, R.; Markham, A.F.; Coletta, P.L. Development of orthotopic tumour models using ultrasound-guided intrahepatic injection. Sci. Rep. 2019, 9, 9904. [CrossRef]

209. Hidalgo, M.; Amant, F.; Biankin, A.V.; Budinská, E.; Byrne, A.T.; Caldas, C.; Clarke, R.B.; de Jong, S.; Jonkers, J.; Mælandsmo, G.M.; et al. Patient-derived xenograft models: An emerging platform for translational cancer research. Cancer Discov. 2014, 4, 998-1013. [CrossRef]

210. Sveen, A.; Bruun, J.; Eide, P.W.; Eilertsen, I.A.; Ramirez, L.; Murumägi, A.; Arjama, M.; Danielsen, S.A.; Kryeziu, K.; Elez, E.; et al. Colorectal Cancer Consensus Molecular Subtypes Translated to Preclinical Models Uncover Potentially Targetable Cancer Cell Dependencies. Clin. Cancer Res. 2018, 24, 794-806. [CrossRef] 
211. Drapkin, B.J.; George, J.; Christensen, C.L.; Mino-Kenudson, M.; Dries, R.; Sundaresan, T.; Phat, S.; Myers, D.T.; Zhong, J.; Igo, P.; et al. Genomic and Functional Fidelity of Small Cell Lung Cancer Patient-Derived Xenografts. Cancer Discov. 2018, 8, 600-615. [CrossRef] [PubMed]

212. Friedman, A.A.; Xia, Y.; Trippa, L.; Le, L.P.; Igras, V.; Frederick, D.T.; Wargo, J.A.; Tanabe, K.K.; Lawrence, D.P.; Neuberg, D.S.; et al. Feasibility of Ultra-High-Throughput Functional Screening of Melanoma Biopsies for Discovery of Novel Cancer Drug Combinations. Clin. Cancer Res. 2017, 23, 4680-4692. [CrossRef] [PubMed]

213. Peraldo Neia, C.; Cavalloni, G.; Chiorino, G.; Ostano, P.; Aglietta, M.; Leone, F. Gene and microRNA modulation upon trabectedin treatment in a human intrahepatic cholangiocarcinoma paired patient derived xenograft and cell line. Oncotarget 2016, 7, 86766-86780. [CrossRef] [PubMed]

214. Peraldo-Neia, C.; Cavalloni, G.; Soster, M.; Gammaitoni, L.; Marchiò, S.; Sassi, F.; Trusolino, L.; Bertotti, A.; Medico, E.; Capussotti, L.; et al. Anti-cancer effect and gene modulation of ET-743 in human biliary tract carcinoma preclinical models. BMC Cancer 2014, 14, 918. [CrossRef]

215. Wang, Y.; Ding, X.; Wang, S.; Moser, C.D.; Shaleh, H.M.; Mohamed, E.A.; Chaiteerakij, R.; Allotey, L.K.; Chen, G.; Miyabe, K.; et al. Antitumor effect of FGFR inhibitors on a novel cholangiocarcinoma patient derived xenograft mouse model endogenously expressing an FGFR2-CCDC6 fusion protein. Cancer Lett. 2016, 380, 163-173. [CrossRef]

216. Saha, S.K.; Gordan, J.D.; Kleinstiver, B.P.; Vu, P.; Najem, M.S.; Yeo, J.C.; Shi, L.; Kato, Y.; Levin, R.S.; Webber, J.T.; et al. Isocitrate Dehydrogenase Mutations Confer Dasatinib Hypersensitivity and SRC Dependence in Intrahepatic Cholangiocarcinoma. Cancer Discov. 2016, 6, 727-739. [CrossRef]

217. Kabashima, A.; Hirsova, P.; Bronk, S.F.; Hernandez, M.C.; Truty, M.J.; Rizvi, S.; Kaufmann, S.H.; Gores, G.J. Fibroblast growth factor receptor inhibition induces loss of matrix MCL1 and necrosis in cholangiocarcinoma. J. Hepatol. 2018, 68, 1228-1238. [CrossRef]

218. Garcia, P.L.; Miller, A.L.; Gamblin, T.L.; Council, L.N.; Christein, J.D.; Arnoletti, J.P.; Heslin, M.J.; Reddy, S.; Richardson, J.H.; Cui, X.; et al. JQ1 Induces DNA Damage and Apoptosis, and Inhibits Tumor Growth in a Patient-Derived Xenograft Model of Cholangiocarcinoma. Mol. Cancer Ther. 2018, 17, 107-118. [CrossRef]

219. Mancarella, S.; Serino, G.; Dituri, F.; Cigliano, A.; Ribback, S.; Wang, J.; Chen, X.; Calvisi, D.F.; Giannelli, G. Crenigacestat, a selective NOTCH1 inhibitor, reduces intrahepatic cholangiocarcinoma progression by blocking VEGFA/DLL4/MMP13 axis. Cell Death Differ. 2020, 27, 2330-2343. [CrossRef]

220. Chen, H.D.; Huang, C.S.; Xu, Q.C.; Li, F.; Huang, X.T.; Wang, J.Q.; Li, S.J.; Zhao, W.; Yin, X.Y. Therapeutic Targeting of CDK7 Suppresses Tumor Progression in Intrahepatic Cholangiocarcinoma. Int. J. Biol. Sci. 2020, 16, 1207-1217. [CrossRef]

221. Wang, C.; Lv, H.; Yang, W.; Li, T.; Fang, T.; Lv, G.; Han, Q.; Dong, L.; Jiang, T.; Jiang, B.; et al. SVCT-2 determines the sensitivity to ascorbate-induced cell death in cholangiocarcinoma cell lines and patient derived xenografts. Cancer Lett. 2017, 398, 1-11. [CrossRef] [PubMed] 